\title{
On the discourse function of particles in post-initial position
}

\author{
Elena Karagjosova \\ Department of Linguistics \\ Stuttgart University \\ Keplerstraße 17 \\ D - 70174 Stuttgart \\ Germany \\ elena.karagjosova@ling.uni-stuttgart.de
}

\begin{abstract}
The paper presents a corpus-based information-structural analysis of the German discourse particles aber and auch in the so-called post-initial position, i.e. between the pre-field constituent and the finite verb in main clauses. Based on corpus data, I argue that aber and auch in this position mark the border between the focus and the background of the sentence that hosts them. By doing this, they essentially contribute to identifying relevant alternatives involved in focus interpretation and discourse interpretation in general. In this way, the placement of particles in postinitial position facilitates interpretation by providing processing instructions to the reader/hearer and by ruling out ambiguities. The analysis argues thus against existing accounts of the discourse function of post-initial particles in terms of indicating association with topic and topic shift.
\end{abstract}

Keywords: adversative and additive connectors, post-initial position, focus-background division, discourse interpretation

\section{Introduction}

In this paper, I present a corpus-based information-structural analysis of an understudied construction in German in which a discourse particle appears between the first constituent and the finite verb in German main clauses. This position has been referred to as the post-initial position ("Nacherstposition", cf. Pasch et al. 2003). Consider (1) where the adversative connector aber ('but, however') is placed in a position between the first constituent (also called the pre-field constituent, the object-NP Den grössten Applaus) and the finite verb. ${ }^{1}$

${ }^{1}$ I use the terms discourse particles and discourse connectors synonymously to refer to a functional class of words including conjunctions, adverbs and particles, following the classification of German connectors in Pasch et al. (2003). 
(1) Per Losentscheid wurde die Reihenfolge festgelegt, Otto musste als Erster ran - und überzeugte. [Den grössten Applaus $]_{\text {prefield }}$ aber heimsten ${ }_{\text {fin.verb }}$ andere ein. $^{2}$

'The order was decided by drawing lots, Otto was first to go - and he did a splendid job. But the loudest applause got others.'

The placement of a particle between the pre-field constituent and the finite verb poses various puzzles with respect to the syntax, the semantics and the discourse function of this construction. First of all, it is a standard assumption that German is a verbsecond language in which the position before the finite verb in main clauses is filled by a single constituent (cf. also table 1). The placement of a discourse connector after the first constituent interferes with this picture, and the construction raises the question of its correct syntactic analysis. Secondly, the position between the initial constituent and the finite verb is not available for all discourse connectors. For instance, among the connectors capable of occupying the post-inital position are the adversative connector aber and the additive particle auch, whereas for other additive (e.g. außerdem, ebenfalls) and adversative (doch) connectors, the post-initial position is not available. This raises the question of what makes some connectors capable of occupying the postinitial position, but not others. And thirdly, since there are other positions in the sentence in which a connector may appear, as shown in table 1 for aber, it is far from clear what makes the placement of connectors in this position necessary, i.e. whether/in what way the particles have a special function or different interpretation in comparison to other positions that they may occupy.

Table 1: The German matrix sentence with the "post-initial position"

\begin{tabular}{llllll}
\hline $\begin{array}{l}\text { Null } \\
\text { position }\end{array}$ & Pre-field & $\begin{array}{l}\text { Postinitial } \\
\text { position }\end{array}$ & $\begin{array}{l}\text { Left } \\
\text { sentence } \\
\text { bracket }\end{array}$ & $\begin{array}{l}\text { Middle } \\
\text { field }\end{array}$ & $\begin{array}{l}\text { Right } \\
\text { sentence } \\
\text { bracket }\end{array}$ \\
\hline \multirow{3}{*}{ Aber } & $\begin{array}{l}\text { Den grössten Applaus } \\
\text { den grössten Applaus }\end{array}$ & & heimsten & aber andere & ein. \\
& Den grössten Applaus & aber & heimsten & andere & ein. \\
& heimsten & andere & ein. \\
\hline
\end{tabular}

It is the primary aim of this paper to investigate the discourse function of postinitial particles, i.e. to answer the question of whether and in what way the function of a particle in this position is different from the one in its other positions, and how this possible difference relates to their semantics. I focus in particular on aber and auch for which sophisticated formal-semantic analyses exist.

Although the paper does not aim at contributing to the syntactic aspect of the construction, and it does not provide an analysis of the syntactic behavior and distributional restrictions of the investigated particles, the findings on the discourse function of aber and auch shed new light on these two issues, providing arguments for and against possible

\footnotetext{
${ }^{2}$ Source: Hamburger Morgenpost, 26.01.2009, S. 1-2-3; Triumph für HSV-Boss Hoffmann.
} 
syntactic analyses and offering a possible explanation of the distributional restrictions in terms of disambiguation. I briefly discuss the syntactic aspect of the construction in section 2.4 and suggest in section 5 how the results of my analysis relate to the question of the correct syntactic analysis of post-initial particles.

To illustrate the relevance of the question of the discourse function of connectors in post-initial position, let us take a brief look at auch. Auch can be placed in front of the pre-field constituent which is focussed, cf. (2-a), or in the middle field, cf. (2-c). ${ }^{3}$ In addition, it may also appear in the post-initial position, as shown by (2-b). ${ }^{4}$

(2) Wayne McGregor erschliesst dem Tanz neue Formen. Deshalb ist er gefragt.

'Wayne McGregor opens up new dance forms. This is why he is sought-after.'

a. [Auch darum $]_{\text {prefield }}$ haben $_{\text {fin.verb }}$ bereits "Die Welt" und die "Süddeutsche Zeitung" über seinen Auftritt ausführlich berichtet.

"This is another reason why "Die Welt" and the "Süddeutsche Zeitung" report extensively on his performance.'

b. [Darum $]_{\text {prefield }}$ auch haben fin.verb $_{\text {bereits }}$ "Die Welt" und die "Süddeutsche Zeitung" über seinen Auftritt ausführlich berichtet.

"This is also why /For the same reason "Die Welt" and the "Süddeutsche Zeitung" reported extensively on his performance.'

c. Darum $_{\text {prefield }}$ haben $_{\text {fin.verb }}$ bereits "Die Welt" und die "Süddeutsche Zeitung" auch $_{\text {middlefield }}$ über seinen Auftritt ausführlich berichtet.

"This is why "Die Welt" and the "Süddeutsche Zeitung" reported extensively on his performance, too.'

Intuitively, there is a substantial difference in the interpretation of the sentences. Most striking is however the difference between (2-a) and (2-b). Although in both cases the particle seems to associate in some way with the pre-field constituent, the interaction between the two elements has two completely different effects. A straightforward explanation for the different interpretation is of course the fact that whereas the pre-field constituent in (2-a) is accented and thus activates alternative reasons for the event described in the auch-sentence, the pre-field constituent in (2-b) is not focused and no alternative reasons are activated. This difference in interpretation follows from the well-known property of focus particles like auch to associate with alternative-evoking expressions. On the other hand, existing theories of focus particles do not seem to be able to explain the different nature of the interaction between post-initial auch and the pre-field element.

A similar, albeit more subtle contrast can be observed when comparing the different uses of aber. Next to the post-initial position (3-a), aber can fill the so-called null-

\footnotetext{
${ }^{3}$ In the middle-field, auch may be either accented or unaccented, which renders different interpretations. At this point this circumstance is irrelevant, but it will be taken up in section 4.2.

${ }^{4}$ This is a slightly abridged version of a corpus example discussed in more detail in section 4.2 under number (30). Source: Braunschweiger Zeitung, 02.05.2008; Tanz im Takt von Gehirnströmungen und Lauf der Windhunde.
} 
$\operatorname{position}^{5}(3-\mathrm{c})$, and it can also be placed in the middle field (3-b) (cf. also table 2):

(3) Per Losentscheid wurde die Reihenfolge festgelegt, Otto musste als Erster ran und überzeugte.

a. [Den grössten Applaus $]_{\text {prefield }}$ aber heimsten fin.verb $_{\text {andere ein. }}$

b. [Den grössten Applaus] $]_{\text {prefield }}$ heimsten ${ }_{\text {fin.verb }} \mathbf{a b e r}_{\text {middlefield }}$ andere ein.

c. Aber $_{\text {nullpos. }}[\text { den grössten Applaus }]_{\text {prefield }}$ heimsten fin.verb $_{\text {andere ein. }}$

Again, a comparison between the three aber-positions shows that there is a subtle difference between the three variants. This difference can be described not as much in terms of interpretation as in terms of discourse coherence. Intuitively, the version with postinitial aber renders the most natural continuation of the discourse where the position of the particle indicates that the intended interpretation of the discourse is based on a contrast between doing a splendid job and getting the biggest applause. A plausible way of thinking of the two as contrasting with each other is offered by the assumption that when one does a splendid job, one should get applause. Based on this relation between the two elements, the intended interpretation can be derived in terms of contrast between Otto who should have received the biggest applause and "others" who in fact have received it. This interpretation is not as prominent or easily derivable in the other two cases. Although the role of post-initial aber in reconstructing the intended interpretation has been noticed before, the subtle mechanisms behind this have not been studied in detail.

The way I go about in pursuing the goal of determining the discourse function of postinitial aber and auch is as follows. I start from existing work, which, based on corpus data and the analysis of the relation between the pre-field constituent and preceding context, puts forward two different assumptions about the discourse function of particles in post-initial position: (i) that they indicate topic shift (Breindl 2008) and (ii) that they make information explicit that must be otherwise inferred from the context (Metrich and Courdier 1995). In order to be able to test these assumptions, I carry out a corpus study that sheds more light on the relation between the pre-field constituent and preceding discourse on the one hand and between the pre-field constituent and the particle on the other. Based on the results of this corpus study and the semantics of aber and auch, I propose an alternative explanation of the role of these post-initial particles in discourse. In doing this, I rely on existing semantic accounts of the two connectors, which however either do not deal with the post-initial uses or do this only marginally. I show that current semantic models do not apply straightforwardly to post-initial aber and auch and suggest how they need to be adjusted or refined in the light of the new data. For reasons of space, I do not provide a full semantic analysis of the connectors but leave

\footnotetext{
${ }^{5}$ I use this term following Pasch et al. (2003: 70) where it refers to the position in the linear structure of the German sentence that is located before the pre-field. According to Pasch et al., this position can be occupied, among other elements, by sentence connectors like aber in (3-c) or allerdings below, where the connector is accented and prosodically/graphically separated from its host:
}

(i) Allerdings: Der gute Wille allein genügt nicht. ('However: Good will alone does not suffice.') 
this issue for future work.

The results of my study falsify the topic-shift assumption and give substance to the rather abstract second assumption. I show in particular that the discourse function of post-initial aber and auch should be described in terms of marking the border between the (new-information) focus and the background of the sentence that hosts them. In doing this, they unambiguously identify alternative generating expressions and facilitate the interpretation of the sentence and its relation to existing discourse in a way that is determined by their semantics. More specifically, I argue that post-initial auch indicates that a focus alternative applies for the background element, whereas post-initial aber indicates that the denotation of the focus does not apply for some alternative of the background element, or, conversely, that an alternative of the focus does not apply for the background. In addition, I argue that placing aber post-initially in most cases triggers the activation of alternatives to the pre-field constituent, whereas placing auch postinitially triggers the identification of the pre-field constituent as carrying information that is shared by both the proposition of the auch-sentence and the preceding sentence.

The paper is structured as follows. In the next section, I briefly present and discuss the previous approaches to the discourse function of post-initial German particles. A separate subsection provides a brief discussion of the possible ways of analyzing the syntax of constructions with post-initial particles. Section 3 presents the corpus-based investigation carried out with the purpose of testing the existing assumptions of the discourse function of post-initial particles. Based on the results of this investigation, as well as on the discussion of existing semantic accounts of the particles, my alternative proposal is presented in section 4. Finally, section 5 presents conclusions and outlook.

\section{Previous work}

In this section, I briefly present the previous accounts of the discourse function of postinitial particles and then discuss their shortcomings that motivate a new, more systematic corpus-based analysis described in the next section. At the end of the section, I also briefly address syntactic aspects of the construction which have not been discussed in these previous accounts.

\subsection{Breindl (2008)}

Breindl (2008) provides an information-structural analysis of the construction in general, in which she claims that the constituent in the pre-field is a topic that is different from the topic of the preceding sentence. Based on this observation, she puts forward the assumption that post-initial particles in general indicate "topic shift", however without providing a precise definition of this rather intuitive notion. Breindl largely considers adversative connectors like aber, jedoch, hingegen and causal connectors like nämlich ('namely'). She argues that the pre-field constituent, or the "associate" of the postinitial particle, may be one of three categories of topic - shifting topic, contrastive topic or frame-setting topic, and that a fourth type of topic, called constant topic, is not an 
appropriate associate.

Breindl's shifting topic refers to the case where the topic of the current sentence was (part of) the focus in the preceding context: ${ }^{6}$

(4) $\quad[\mathrm{Wir}]_{T_{1}}$ versuchten $\mathbf{i h n}_{F_{1}}$ umzustimmen. $[\mathbf{E r}]_{T_{2}=F_{1}}$ aber liess sich auf keine Weise zum Weiterlesen bringen. (Breindl 2008: 39, exp. (33))

'We tried to change his mind, but we did not manage to make him read further.'

By contrastive topic Breindl refers to cases of pairwise contrast involving two contrasting topics and two contrasting comments, as in (5-a), but she also admits cases where the pre-field topic of the particle host is contrastively related to some prosodically not accentuated background element in the preceding context, as in (5-b), or to a focus, thus assuming that a contrastive topic must be contrastively bound to the preceding context, but not necessarily to a preceding topic.

(5) a. [Die Bohrmaschine unterm Weihnachtsbaum $]_{T_{1}}$ [hält den Mann verlässlich von der Frau fern $]_{C_{1}}[\ldots]$ [Die Reise nach Mallorca $]_{T_{2}}$ hingegen [bindet den Schenkenden und die Beschenkte für 2 Wochen aneinander $]_{C_{2}}$. (Breindl 2008: 39, exp. (35))

'The drill under the Christmas tree keeps the husband at a safe distance from his wife. The trip to Mallorca however ties the giver and the recepient to each other for 2 weeks.'

b. Der Teufel soll sie alle holen! Es mag sein, dass er manchmal ein Eichhörnchen ist, sicherlich jedoch hat er weder Hörner noch Klumpfuss [...] (Breindl 2008: 31, exp. (13a)))

'To hell with them all! He might be sometimes a squirrel, but he certainly has neither beaks nor club foot.'

With frame-setting topics Breindl, following Chafe (1976: 50), refers to temporal, local and other sentence adverbials that limit "the applicability of the main predication to a certain restricted domain". Breindl observes that such topics in front of post-initial particles may be at the same time shifting (as in (6-a)) or contrastive topics (as in (6-b)):

(6) a. Der Meister Dudel sollte am nächsten Morgen durch Schilda ziehen, mit seiner Flöte die Ratten und Mäuse an sich locken und sie danach [an den Schildsee $]_{F_{1}}$ hinausführen. [Dort $]_{T_{2}=F_{1}}$ aber werde ein Boot bereitstehen, das er besteigen sollte. (Breindl 2008: 42, exp. (42))

'Master Dudel was supposed to walk through Schilda on the next morning, to bait the rats and mice with his fleet and to lead them thereafter to the Schild lake. There however a boat would wait for him to embark.'

b. Aber [der Text, der damals beschlossen wurde $]_{T_{1}}$, stiess seinerzeit auf wenig Interesse und Beachtung. [Heute $]_{T_{2}}$ jedoch könnte seine Kenntnis dazu beitragen, die Diskussion aus ihrer Einseitigkeit herauszuführen. (Breindl

\footnotetext{
${ }^{6}$ This notion corresponds to Daneš' (1974) classical notion of linear textual progression.
} 
2008: 42, exp. (43))

'But the text that was agreed upon back then was met with little interest and attention. Nowadays, however, the knowledge of it could lead the discussion out of its lopsidedness.'

Finally, constant topic refers to the case where the topic of the sentence is identical to the topic of the preceding sentence. ${ }^{7}$ A constant topic is often realized as an anaphor. Breindl's crucial observation is that this kind of topic cannot be followed by a post-initial connector:

$[\text { Die Mägde }]_{T_{1}}$ sind faul. $[\text { Sie }]_{T_{2}=T_{1}}\left\{\begin{array}{c}\text { \# nämlich wollen } \\ \text { wollen nämlich }\end{array}\right\}$ nur essen. $^{8}$

'The maids are lazy. They NAMELY only want to eat.'

In contrast to constant topic, both shifting and contrastive topics involve a change of topic. Breindl observes a special affinity of contrastive topics to adversative connectors in post-initial position and conjectures that since topic continuity is the preferred, more economic option, marking a shift in topic is desirable from a recipient perspective. She therefore conjectures that the construction with post-initial connectors is very useful in precisely such cases and concludes that the particles following the pre-field constituent associate with the topic of their host with the purpose of marking topic shift.

\subsection{Metrich and Courdier (1995)}

Metrich and Courdier (1995) focus on post-initial aber and provide a brief morphosyntactic characterization of the constituents that occupy the pre-field in front of postinitial aber, as well as an intuitive, pre-theoretical analysis of the formal relation between the pre-field element and the preceding sentence. According to their findings, there are no limitations as to the possible phrases that occur in combination with post-initial aber, no matter what grammatical category, syntactic function or information-structural status they have. They point out NPs as the most frequent ones, followed by PPs, adverbs, non-finite verb forms, verbal complexes, connectors with temporal, logical and text structuring function, as well as modal adverbs and negation particles.

Considering the formal relation between the pre-field element and the preceding sentence, Metrich and Courdier identify two basic constellations that they call "contrast" and "resumption". Contrast holds when the pre-field element corresponds to an element in the preceding sentence that semantically and functionally (but not necessarily morpho-syntactically) belongs "to the same paradigm", including phrases as well as modal adverbs and connectors and possibly but not necessarily involving syntactic parallelism. This type of constellation corresponds to Breindl's cases of contrastive topic illustrated by (5-a) and (5-b). The second type, resumption, involves an anaphoric link or paraphrase/repetition of some element of the preceding sentence, or of the information contained in some element of the preceding sentence, as in (8).

\footnotetext{
${ }^{7}$ This notion corresponds to Daneš' (1974) notion of constant theme.

${ }^{8}$ This is a shortened version of Breindl's (2008: 38) example (31a).
} 
(8) a. Er mochte hoffen, dass die Deutschnationalen [...] die Fraktion zur Gefolgschaft gewinnen würden. Dies aber war sein Irrtum. (exp. (63) in Metrich and Courdier (1995: 290))

"He may have hoped that the "German-nationals" would win the support of the fraction. This however was his mistake.'

b. Sesshaftigkeit und Arbeit bedeuteten ihm mehr als Pilgerschaft und freiwilliges Exil. Sesshaftigkeit aber setzt Besitz voraus. (exp. (66) in Metrich and Courdier (1995: 290))

'Settledness and work meant more to him than pilgrimage and voluntary exile. Settledness however presupposes possession.'

Besides the two most frequently found constellations above, Metrich and Courdier identify some less clear-cut cases as subtypes of the major types, which they call implicit contrast and implicit resumption. An implicit contrast is present when the pre-field element is contrasted with some information in the context that is not explicitly expressed but "can be inferred from the interplay between the pre-field element and the context". This constellation is illustrated by (9) where the military aspect is contrasted to the religious aspect and the latter is only indirectly "addressed" in the first sentence.

(9) Noch war Sachsen dem neuen Glauben nicht völlig gewonnen. Militärisch aber lag das Land am Boden. (exp. (68) in Metrich and Courdier (1995: 291)) 'Sachsen was not yet won for the new faith. Militarily, the land was ruined.'

Similarly, implicit resumption is defined as resumption which involves inferences based on lexical or world knowledge. An example is (10) where presumably the implicitness of the resumption is justified by the fact that an inference from "children" to "the children's parents" can be made based on world knowledge.

(10) Über eine Million Kinder in Deutschland sehen die Welt in falschen Farben. Die meisten Eltern aber wissen nicht, dass [...] (exp. (71) in Metrich and Courdier (1995: 292))

'More than a million children in Germany see the world in wrong colours. Most parents however do not know that...'

Finally, a constellation called turning point in the course of events involves the introduction of a phrase in the pre-field that is new to discourse (typically a temporal expression like nun 'now', eines Tages 'one day', inzwischen 'in the meantime') that truncates the preceding course of events thus establishing a contrast relation between the way things are before and after this point. Metrich and Courdier argue that this type differs from the implicit contrast type where the pre-field element is related to some implicit information in the context by means of inference.

(11) Karl requisierte auch diese Fürstenhöfe. Dann aber ging er noch einen Schritt weiter und [...] (exp. (74) in Metrich and Courdier (1995: 292))

'Karl confiscated these courts, too. Then however he made a further step.' 
Concerning the function of post-initial aber, Metrich and Courdier draw the general conclusion that its placement in the post-initial position serves the purpose of making explicit information that otherwise must be inferred from the context.

\subsection{Discussion}

Although both analyses presented in the previous section provide a number of valuable observations, they have certain weaknesses and limitations which I discuss below in turn.

Breindl's information-structural account is more systematic than Metrich and Courdier's, which is too pre-theoretic, but it suffers in turn from insufficient accuracy in defining the relevant theoretical notions. And more crucially, Breindl's assumption concerning topic association and topic shift seems both empirically and theoretically problematic.

First, the four topic categories by means of which Breindl characterizes the information status of the pre-field constituent form a heterogenous group. Frame-setting topic represents a notion that belongs to the sentence level, together with the notion of aboutness topic. The notion aboutness topic is standardly understood as the constituent that identifies the entity about which information is given by the rest of the sentence, the comment (cf. Reinhart 1981, Krifka 2007). In contrast, Breindl's "constant" and "shifting topic" represent particular configurations that a sentence topic, be it aboutness or frame-setting topic, may be involved in in terms of its relation to preceding discourse. Further, contrastive topic is a notion that can be understood in several different ways, as also pointed out in Sæbø (2004: 202): (i) as an accented sentence (aboutness) topic (e.g. S-topics in Büring 1999, cf. also Krifka 1999 and Jacobs's 1997 I-topicalization) that evokes alternatives in the sense of Rooth (1992), or (ii) as an (aboutness) topic that is not necessarily accented but is contrastive in a context which licenses some alternative expression. Breindl's contrastive topic seems to allude to both these interpretations of the term. On the other hand, she assumes with Jacobs (2001) that contrastive topics may involve also frame-setting topics, apart from aboutness topics, as well as constituents that are denied a topical status. It seems therefore that what Breindl's "contrastive topic" represents is in practice, next to constant and shifting topic, a further type of discourse configuration in which the pre-field constituent may be involved in terms of its relation to preceding discourse.

Second, the notion of topic shift used by Breindl is not clearly explicated. It seems that Breindl uses this term in two ways, (i) in purely formal terms, where the pre-field constituent is different from the one in the preceding sentence, and (ii) in terms of the role of the topical constituent in what has been called the thematic progression of the discourse, in the sense of the relation of an aboutness topic to the topic(s) in preceding context (cf. Daneš 1974). The latter notion is also related to the notion of discourse topic, often formalized in terms of the current question under discussion (QUD) that a sentence in discourse can be seen as an answer to (cf. Roberts 1996). As a consequence of this insufficient notional transparency, it is far from clear how to identify a topic shift. The problem can be illustrated by cases like Metrich and Courdier's example in (11), where one could ask whether they qualify as cases of topic shift. In (11), the framesetting topic dann is neither a shifting nor a contrastive topic. It is however newly 
introduced and different from the aboutness topic of the preceding sentence, Karl. On the other hand, the aboutness topic of the preceding sentence, Karl, is also the aboutness topic of the aber-sentence. It seems that although the frame-setting topic is new, both sentences are about the deeds of Karl, which is their common discourse topic that remains constant throughout the entire discourse segment. What the example suggests is that a formal shift of topic at the sentence level does not necessarily imply a topic shift at the discourse level, which has already been observed in relation to other post-initial particles (e.g. Karagjosova 2011 on nämlich). Defining an adequate notion of topic shift thus requires distinguishing between sentence topic in terms of a topical constituent (aboutness topic) and discourse topic in terms of the implicit question (QUD) that the current utterance can be construed as an answer to, a distinction that has been recently discussed in Roberts (2011). According to Roberts, the two notions are related in the sense that the aboutness topic is part of the QUD. Using this distinction as a diagnostic tool, we can see that in (11), both sentences have the same overarching QUD, cf. (12).

$$
\begin{aligned}
& \text { Karl requisierte auch diese Fürstenhöfe. } \\
& \text { What about Karl? (aboutness topic) } \\
& \text { What did Karl do? (QUD) }
\end{aligned}
$$

Dann aber ging er noch einen Schritt weiter und ... What did Karl do (then)? (QUD)

What cases like (11) further suggest is that it makes sense to talk about topic shift (i) only in connection with aboutness topics, and, (ii), only with respect to their role in the thematic progression of the discourse. While Breindl seems to be aware of the importance of the notion of thematic progression, her topic categories are defined solely as a formal shift involving a pre-field constituent which may be a topic of either type, aboutness or frame-setting, but which may also be a non-topical constituent.

Finally, Breindl's topic shift assumption seems to be an undergeneralization since cases like (8-b) do not involve topic shift of any thinkable sort. On Breindl's analysis, this example should be categorized as a case of constant topic, and such cases are not allowed in her model. The sentence is however perfectly acceptable.

Turning to Metrich and Courdier's account, it should be noted that it is not sufficiently adequate either. Their analysis of the relation between the pre-field element and the preceding sentence seems too ad hoc, and their assessment of the role of post-initial aber is too abstract. The classification of the constellations into which the pre-field element enters with some element in the preceding discourse is an issue that is most interesting for the purpose of the present study and is in a way a pre-theoretical version of the analysis proposed by Breindl. It seems that their category "contrast" corresponds to Breindl's contrastive topic, and the category "resumption" corresponds partly to Breindl's constant topic and partly to her shifting topic. However, it is far from clear what criteria govern this classification. For instance, (8-b) which is categorized as a case of resumption, could just as well be categorized as a case of contrast, or at least implicit contrast, since on the most plausible interpretation of this example, the expression Sesshaftigkeit in front of the post-initial particle is contrasted to the expression 
Pilgerschaft in the preceding sentence, to the effect that settledness presupposes possession, whereas pilgrimage doesn't. Even more problematic is the sub-categorization in "implicit contrast" and "implicit resumption", where the problem seems to be the lack of distinction between formal and semantic criteria involved in establishing this classification.

The discussion above calls for a more systematic analysis of the discourse function of particles in post-initial position. In a corpus study that will be presented in the next section, I try to overcome the limitations of the previous analyses by taking into account both the morpho-syntactic and information-structural type of the pre-field constituent and by keeping the formal and the semantic level, as well as the sentence level and the discourse level apart. In particular, I distinguish between (i) the information-structural status of the pre-field constituent depending on its syntactic and semantic type, and (ii) the type of constellation in which the pre-field element is involved based on its formal relation to preceding context.

\subsection{A brief note on syntax}

At least as important and intriguing as the question of the discourse function of postinitial particles is the likewise still unresolved question of the syntactic status of connectors in this position. Does the connector form a single constituent together with the pre-field element, or is it rather an independent adjunct? The latter view would argue for the assumption of a separate position for these connectors and thus challenge the standard conception of German as a verb-second language in which the finite verb immediately follows a single pre-field constituent in the matrix clause. The view that is promoted in Pasch et al. (2003: 70-71) where post-initial particles are discussed in some detail, is that in order to keep the V2-constraint, one has to assume some internal structuring of the pre-field. They account for post-initial particles, as well as focus particles preposed to the pre-field element (such as sogar 'even', nur 'only' and auch as in (2-a)), by assuming a post-initial and a pre-initial ("Vorerstposition") position within the pre-field respectively (cf. table 2). However, Pasch et al. (2003) do not offer a proper syntactic analysis of post-initial connectors.

Table 2: The German matrix sentence with an internally structured pre-field

\begin{tabular}{|c|c|c|c|c|c|c|}
\hline $\begin{array}{l}\text { Null- } \\
\text { position }\end{array}$ & $\begin{array}{l}\text { Pre-initial } \\
\text { position }\end{array}$ & Pre-field & $\begin{array}{l}\text { Post-initial } \\
\text { position }\end{array}$ & $\begin{array}{l}\text { Left } \\
\text { sentence } \\
\text { bracket }\end{array}$ & $\begin{array}{l}\text { Middle } \\
\text { field }\end{array}$ & $\begin{array}{l}\text { Right } \\
\text { sentence } \\
\text { bracket }\end{array}$ \\
\hline Aber & Sogar & $\begin{array}{l}\text { Den grössten Applaus } \\
\text { den grössten Applaus } \\
\text { Den grössten Applaus } \\
\text { den grössten Applaus }\end{array}$ & aber & $\begin{array}{l}\text { heimsten } \\
\text { heimsten } \\
\text { heimsten } \\
\text { heimsten }\end{array}$ & $\begin{array}{r}\text { aber andere } \\
\text { andere } \\
\text { andere } \\
\text { andere }\end{array}$ & $\begin{array}{l}\text { ein. } \\
\text { ein. } \\
\text { ein. } \\
\text { ein. }\end{array}$ \\
\hline
\end{tabular}

Various cases where more than one constituent is placed before the finite verb in 
German matrix sentences are discussed by Müller (2003, 2005a, 2005b), providing a syntactic analysis of such cases of multiple fronting ("mehrfache Vorfeldbesetzung"). In Müller (2005a), some cases involving focus particles that are preposed or post-posed to a focussed pre-field constituent are also discussed. ${ }^{9}$ There, Müller makes a case against Büring and Hartmann (2001) and Jacobs $(1983,1986)$ who deny the existence of postinitial, or "post-posed" focus particles in their terms, while arguing that preposed focus particles call for an analysis on which the V2-constraint must be given up (cf. also Reis' (2005) massive criticism of Büring and Hartmann (2001)). Instead, Müller argues in favor of analyses of post-posed focus particles in terms of them building complex phrases with the preposed constituent as a head, in line with proposals by Reis (2005) and Fanselow (2004), which makes the V3 question obsolete.

On the other hand, Dürscheid (1989: 26) argues that post-initial adverbials like freilich and immerhin that bear on the entire sentence, rather than the constituent to the left of the adverbial, do not constitute a syntactic unit with the pre-field constituent and should be analyzed as cases of multiple fronting. This view seems to be relevant for the analysis of post-initial aber, since it may be seen as behaving more like post-initial freilich and immerhin, rather than like focus particles such as auch - although aber is focus-sensitive in a way that will be explained in section 4.1, it does not take scope over a single focussed constituent the way focus particles do, which may be suggesting a syntactic analysis different from post-initial auch.

The data on post-initial aber and auch that I present in section 3 suggest that the picture is even more complicated. As I will show in section 4, post-initial aber and auch do not associate with the pre-field constituent in terms of focus, but they do so with the material to their right, which seems to provide evidence against a head analysis. On the other hand, both particles interact semantically also with the pre-field constituent, albeit in a different way. This calls for an analysis in the spirit of Reis and Rosengren (1997) who suggest, without however considering the post-initial placement of auch a viable grammatical option, that auch should be analyzed as an XP adjoining to XPs of all kinds, forming a single constituent with them (thus also arguing against a head analysis of auch).

Since the paper does not aim at contributing to the syntactic aspect of the phenomenon under investigation, the question of the correct syntactic analysis of post-initial aber and auch will not be further pursued. However, I believe that a proper discoursesemantic analysis of post-initial particles should be capable of providing arguments in the one or another direction that could eventually further advance the syntactic issue as well. Especially the observation that post-initial auch behaves differently from pre-initial auch in terms of its interaction with the pre-field constituent, calls for a reconsideration of existing syntactic analyses of auch such as Büring and Hartmann (2001). I will briefly return to this point in section 5. Assessing the exact consequences of the discussion for

\footnotetext{
${ }^{9}$ Müller discusses examples with nur and sogar, but auch is not mentioned. In fact, Altmann (1976) who seems to have first noticed the placement of focus particles to the right of the focussed pre-field constituent argues that auch is not possible in this position. Importantly, his discussion is based on examples with NPs in the pre-field. As I will show in section 3.2, the occurrence of postposed auch is restricted to combinations with constituents other than NPs.
} 
the syntactic analyses of aber and auch must however be left for future work.

\section{A new study}

In this section, I present and discuss the results of a corpus study I have conducted with the purpose of testing the extent to which the topic-association and topic-shift assumption put forward in Breindl (2008) can be validated. ${ }^{10}$ First, I present the corpus and the background assumptions underlying the analysis of the data. Then I present and discuss the results of the corpus study. The results clearly falsify the assumption of association with topic and topic shift and suggest that the focus-background dimension of information structure is more relevant for understanding the discourse function of postinitial aber and auch. This is also supported by the fact that both aber and auch interact semantically with alternative-evoking expressions in the sentence that hosts them. This motivates a discussion of the semantics of the particles that I present in section 4 , based on which I identify their function in terms of marking the focus-background boundary of the sentence in which they occur, thus identifying relevant objects participating in discourse interpretation.

\subsection{Method and background assumptions}

I have analyzed 50 instances of post-initial aber and 50 of auch from the morphosyntactically tagged subcorpus TAGGED-C of the DeReKo-corpus (Deutsches Referenzkorpus) of German newspaper articles developed by the IDS (Institut für deutsche Sprache) in Mannheim. ${ }^{11}$ In order to rule out regional variations, only data stemming from larger German newspapers were considered. For each example, I have annotated the prefield constituent in front of the post-initial particle in terms of (i) its morpho-syntactic and semantic type (e.g. in/definite NP, temporal/local/modal adverbs/PPs), (ii) its information-structural status and (iii) the discourse configuration that characterizes its relation to preceding context.

The morpho-syntactic and information-structural annotation of the pre-field element of the particle host was motivated by the question of the extent to which the assumption that it should be construed as topic, aboutness or frame-setting, can be maintained. Concerning the information-structural division of the sentence, a basic assumption underlying the annotation is that a sentence can be partitioned along two basic independent dimensions, focus-background and topic-comment (cf. e.g. Steube and Späth 2002, Frey 2004, Krifka 2007). The first dimension is related to the question of which entities are represented as new and which as given in the respective context. Focus in this sense is also called "new information focus" and represents the part of the sentence that can be construed as providing new information, e.g. in terms of an answer to some question, or in terms of newly added discourse referents which can be refered to by pronouns in

\footnotetext{
${ }^{10}$ The corpus annotation and analysis presented here is a considerably revised version of the corpus study presented in Deichsel and Karagjosova (2011).

${ }^{11}$ http://www.ids-mannheim.de/cosmas2/.
} 
the following discourse (cf. Götze et al. 2007). Focus (at least in languages like German and English) is prosodically marked. I further assume that focus is semantically interpreted in terms of indicating salient alternatives, i.e. expressions that are type-identical with the focussed expression (cf. Rooth 1992).Background is the remaining part of the sentence that can be construed as given or derivable from the context. ${ }^{12}$

The second dimension divides the sentence into an element denoting an entity, the topic, and some information about this entity, the comment. This dimension involves the notion of aboutness topic mentioned in section 2.3. Aboutness topic is understood in the sense of Reinhart (1981) as denoting the entity about which the rest of the sentence provides information, in analogy to a card-file system where a card file stores information about a certain entity (cf. also Krifka 2007). Aboutness topics are restricted to certain types of constituents (cf. e.g. Götze et al. 2007): specific referents, such as definites, specific indefinites, set-referring universally quantified NPs, generic NPs, i.e. constituents that can be construed as denoting entities about which information can be provided. It has been standardly assumed (e.g. Müller and Sternefeld 1993, Jacobs 2001) that in German, aboutness topics are typically placed in the pre-field of the German sentence. Since the German pre-field may in general be occupied by phrases that may have different information-structural status, such as foci, as well as elements that are denied topical status, such as sentence adverbials like nicht ('not') and quantified phrases, this has lead to the assumption that German does not have a special position for topics. Frey (2004), however, argues that German has a designated position for aboutness topics in the left periphery of the middle field, and that aboutness topics that appear in the pre-field are moved from this position to the pre-field.

An aboutness topic may be accented (with a rising accent, cf. e.g. Büring 1997, 2003), in which case it comes with alternatives and is called "contrastive topic" (cf. also Krifka 2007 and the discussion in 2.3). An aboutness topic need however not be accented. For this reason (and further reasons discussed in section 2.3 as well as further below) I do not differentiate accented from unaccented aboutness topics, neither do I assume a separate contrastive-topic type, unlike Breindl.

Further, it is often assumed that topics represent given information. This is however not necessarily the case, since there may be new topics, i.e. topical constituents introducing new entities in discourse, as shown in e.g. Krifka (2007), which is also one of the motivations for assuming the autonomy of the topic-comment dimension from the focus-background dimension.

In my corpus, I have annotated the constituent in front of post-initial aber and auch for new-information focus and two topical categories, aboutness and frame-setting topic. The annotation of these categories is by and large consistent with the Potsdam annotation guidelines (Götze et al. 2007).

The notion of frame-setting topic that I use is identical with the one used by Breindl (2008). It refers to frame adverbials (e.g. temporal, local, modal, epistemic sentence adverbials and PPs) that set "a spatial, temporal, individual framework within which

\footnotetext{
${ }^{12}$ For a formal account of the focus-background dimension cf. von Stechow (1990) and Krifka (1992).
} 
the main predication holds" (Chafe 1976). ${ }^{13}$ Frame-setting topics are often part of the background but need not be. They differ from aboutness topics in that they do not represent entities about which the rest of the sentence makes a predication (cf. also Götze et al. 2007). ${ }^{14}$

I assume further with Götze et al. (2007) that a sentence may only have one aboutness topic ${ }^{15}$ and one or several frame-setting topics.

I annotated as non-topics pre-field constituents that are not focus but cannot be aboutness topics because of their non-specificity and that cannot be construed as framesetting topics either.

Further, I annotated the corpus data for the type of constellation in which the prefield element is involved based on its formal relation to the preceding context: shifting, constant, contrastive and new. The motivation behind this was that it would allow an assessment of the extent to which a topic shift can be observed. I assume a notion of topic shift that involves aboutness and frame-setting topics in contrastive, shifting and new configurations (cf. also the discussion in section 2.3). On the other hand, I assume that contrastive, shifting and new configurations involving non-topics cannot be seen as cases of topic shift. I define the configurations below.

The shifting type configuration corresponds to Breindl's "shifting topic" introduced in the previous section. It may involve topical as well as non-topical constituents (and is obviously not defined for focal constituents). A shifting type configuration involves a prefield constituent that is identical (in terms of repetition or anaphor) with a constituent that belongs to the focus of the preceding sentence.

The constant type configuration is defined as follows: if the pre-field constituent of the particle host is an aboutness topic, it is in a constant type configuration if it is identical (in terms of repetition or anaphor) with the topical constituent in the preceding sentence, which may be placed in the pre-field or the middle field (cf. the discussion on the position of aboutness topics in German above). ${ }^{16}$ If the pre-field element is a frame-setting topic, or a non-topic, then it is in a constant-type configuration if the element in the pre-field of the preceding sentence is also a frame-setting topic or non-

\footnotetext{
${ }^{13}$ Krifka (2007), following Jacobs (2001), assumes the more narrow notion of frame-setters defined in terms of adverbials denoting domains to which the main predication is restricted, such as "physically" in Physically, Peter is doing fine.

${ }^{14}$ It is therefore not entirely clear whether they belong to one of the two dimensions above or represent an information-structural dimension of their own. Jacobs (2001) treats frame-setters as representing one of his four dimensions of the topic-comment dichotomy. Frey (2004) notes that some frame-setters like "in Germany", as well as local, temporal and modal adverbials, can be regarded as aboutness topics as long as they are referential, since they can then be placed in the topic position in the middle field, whereas non-referential frame-setters like "physically" cannot. The question whether frame-setting topics can be construed as aboutness topics or not is however irrelevant for my purpose which is merely to test whether the pre-field element is always a topic of some kind, regardless which one.

${ }^{15}$ Frey (2004) notes that a sentence may have several aboutness topics, one in the pre-field and one in the middle field. However, it is not entirely clear how this assumption is compatible with the standardly assumed file-card conception of aboutness topics.

${ }^{16}$ Here, as well as with respect to the shifting configuration, possible cases of bridging inference are ignored both for the sake of simplicity and because no such cases were found in my corpus.
} 
topic respectively. ${ }^{17}$

The contrastive configuration is intended to cover on the one hand the cases of contrastive topic proper discussed above. Sentences with such contrastive topics contain two accents, one on the topic in the pre-field and one on the focus in the middle field. Both accents indicate Roothean alternatives, often given in a parallel follow-up sentence (cf. (5-a)). However, besides aboutness topics, also frame-setting topics, as well as nontopical constituents such as quantified phrases have been discussed in relation to the notion of contrastive topic (e.g. Jacobs 2001). Further, as pointed out in section 2.3, there are cases in which topics are unaccented but nevertheless contrastive by virtue of the fact that the preceding context activates alternatives to the entity denoted by the topic. Such alternatives need moreover not be topics themselves but may be constituents in the preceding context that belong to the focus, such as in (13) below, where the alternative to the non-topical pre-field constituent is vieles.

(13) Jol ist ein Fuchs. Er sagt vieles mit einem Augenzwinkern. Eines aber meint er ernst - und trifft den Nagel auf den Kopf: [...] (Hamburger Morgenpost, 06.01.2009, S. 1-32-33; Beckham lobt Jol "Er ist großartig")

'Jol is a fox. He says a lot of things with a wink in his eye. But there is one thing he is serious about - and hits the bull's-eye: ...'

Because of these complicating circumstances, I, unlike Breindl, do not consider "contrastive topic" a topic type, but treat such pre-field constituents in terms of their relation to the preceding sentence, i.e. as being involved in a contrastive configuration with respect to the preceding context. This configuration may involve both topics (aboutness or frame-setting) and non-topics in the pre-field. A crucial requirement for annotating a pre-field element as being in a contrastive discourse configuration is that the preceding context should provide an explicit alternative. What is more, the contrast between the pre-field constituent and its alternative in the context should be inherent in some way, i.e. not induced by explicit contrastive markers like aber. Whether this is the case can be tested by removing the contrastive marker: if the contrast persists, we are dealing with a contrastive configuration. In the case of (8-b) for instance the test would result in annotating the configuration as constant.

Obviously, this last requirement is necessary in order to be able to distinguish the contrastive from the constant type configuration. On the other hand, removing the adversative marker in cases like (9) results in a different configuration that also needs to be distinguished from the contrastive one. I call this configuration new and tag as such pre-field constituents (topics or non-topics) that do not have an explicit corresponding expression or alternative in the immediately preceding context, as in Metrich and Courdier's (11). ${ }^{18}$

\footnotetext{
${ }^{17}$ As already mentioned in footnote 14, according to Frey (2004) it is possible that frame-setting topics can be construed as aboutness topics and placed in the topic position in the middle-field. Also, it is possible that the pre-field is occupied by focal constituents. Since I haven't come across such cases in my corpus data, I will ignore these complications for the purpose of the present study.

${ }^{18}$ Note that the shifting configuration as well as the constant and contrastive ones may be better
} 


\subsection{Results and discussion}

The results of the evaluation of the annotated corpus concerning the morpho-syntactic type of the pre-field constituent, as well as its topical status, are presented in table 3.

Table 3: The pre-field constituent

\begin{tabular}{|c|c|c|c|}
\hline IS category & Morpho-syntactic category & aber & auch \\
\hline aboutness & proper name & 7 & - \\
\hline \multirow[t]{5}{*}{ topic } & definite NP & 8 & - \\
\hline & bare sg/pl NP & 1 & 1 \\
\hline & personal pronoun & 3 & - \\
\hline & propositional anaphor & 2 & 1 \\
\hline & TOTAL & 21 & 2 \\
\hline \multirow{11}{*}{$\begin{array}{l}\text { frame- } \\
\text { setting } \\
\text { topic }\end{array}$} & temporal adverb/AdvP & 9 & - \\
\hline & local PP & 1 & 3 \\
\hline & temporal PP & 3 & 3 \\
\hline & circumstantional PP & 1 & - \\
\hline & local anaphor & - & 1 \\
\hline & temporal anaphor & - & 1 \\
\hline & modal anaphor & - & 1 \\
\hline & als-appositive & 1 & - \\
\hline & epistemic/attitude adverb/PP & 1 & 8 \\
\hline & adverbial AdjP & 2 & - \\
\hline & TOTAL & 18 & 17 \\
\hline \multirow[t]{2}{*}{ focus } & indefinite NP & 1 & - \\
\hline & interrogative pronoun & 2 & - \\
\hline non- & prepositional adverb (causal) & - & 13 \\
\hline \multirow[t]{8}{*}{ topic } & indefinite pronoun & 2 & - \\
\hline & temporal quantifier & 1 & 11 \\
\hline & predicative AdjP & 2 & 5 \\
\hline & participle (predicate) & 1 & - \\
\hline & modal adverb/AdvP & - & 1 \\
\hline & modal PP & 1 & 1 \\
\hline & infinitive verb (predicate) & 1 & - \\
\hline & TOTAL & 8 & 31 \\
\hline
\end{tabular}

The table shows a more accurate but also a more varied picture of the nature of the pre-field constituent in constructions with post-inital aber as compared to Metrich

defined for two neighboring discourse segments rather than sentences since, especially in the case of the contrastive configuration, the explicit alternative of the pre-field element may be two or more sentences back in the discourse context. However, the simpler definitions above suffice for the purpose of the present study. 
and Courdier. It also hints at some restrictions, although no categories can be excluded merely on the basis of the relatively small data set. ${ }^{19}$ For instance, post-initial auch cannot be preceded by nominal constituents (\#Peter/\#Der Mann auch). The table further hints at some affinities: post-initial aber is more frequent with nominal constituents and temporal adverbs, auch with epistemic and attitude adverbs and PPs (vielleicht 'perhaps', wohl 'possibly'), causal prepositional adverbs (such as darum in (2-b)), temporal quantifiers (selten 'seldom', zwei mal 'twice', mehrmals 'several times') and predicative adjectival phrases (as in (14)). Further, both post-initial aber and auch can follow propositional anaphors such as das in (15) which I treat as aboutness topics.

(14) Die klare Ansage heißt: Staat und Religion sind Grenzen gesetzt. Ungewöhnlich klar auch haben sich die Vertreter der Muslime zu Sicherheitspartnerschaften verpflichtet. (Hannoversche Allgemeine, 14.03.2008, S. 2)

'The clear message is: state and religion have certain boundaries. Likewise unusually clearly, representatives of the Muslims committed themselves to security cooperations.'

(15) Mit einem charmanten Schelmenstück begrüßt die niederdeutsche Bühne das neue Jahr. Im Zentrum der verwickelten Story steht Leopold Katteker. [Dreist schmuggelt sich der Nassauer auf den Empfängen der Reichen ein und plündert die Buffets $]_{F}$. Das aber ist noch nichts gegen die Suppe, die er sich einbrockt, als er die Wohlhabenden zur Gründung eines Hilfskomitees für Arme überredet. (Hamburger Morgenpost, 18.01.2009, S. 17; Kaviar und Linsen)

'The low-German stage welcomes the new year with a charming beggar play. At the core of the complicated story is Leopold Katteker. The guy from Nassau smuggles himself perkily in the receptions of the rich and plunders the buffets. This however is nothing compared to the situation he gets himself into, when he convinces the rich to establish a help committee for the poor.'

It should be noted that the bulk of the data presented in table 3 has the limited value of showing the distribution of constituents in the pre-field with the purpose of identifying their topical status, and that the restrictions and affinities pointed at above, that do not directly relate to the aims of the present study, will not be further analyzed. The essence of table 3 that is relevant for the current study is presented in table 4 which presents the occurrences of the two particles with pre-field constituents categorized with respect to their information-structural status (focus, aboutness and frame-setting topic), as well as with non-topics, in percentage. The fact that as many as $62 \%$ of the auch examples and $16 \%$ of the aber examples involve non-topics (next to $6 \%$ involving focus) is already a strong indication that Breindl's assumption that post-initial particles associate with topics is not general enough.

The results concerning the relation between the pre-field constituent and the preceding context are presented in table 5. These results clearly indicate that the topic

\footnotetext{
${ }^{19}$ It should also be noted that constructions with post-initial aber are much more frequent than such with post-initial auch.
} 
Table 4: Particles and information-structural category of pre-field element

\begin{tabular}{lllll}
\hline Particles & aboutness topic & frame-setting topic & non-topic & focus \\
\hline aber & $42 \%$ & $36 \%$ & $16 \%$ & $6 \%$ \\
auch & $4 \%$ & $34 \%$ & $62 \%$ & - \\
\hline
\end{tabular}

shift assumption is not tenable. The results for aber are not unexpected, especially as regards the considerable amount of cases of contrastive configurations, as well as the shifting configurations. Although the new topics, that are relatively frequent with aber, can also be considered as involving a shift of sentence topic in some pre-theoretical sense, the not insignificant amount of cases of constant topics preceding auch and the mere existence of such cases with aber, as well as the cases of non-topics, represent a strong counterevidence for Breindl's topic shift assumption. ${ }^{20}$

Table 5: The relation to context: configurations

\begin{tabular}{lllll}
\hline & $\begin{array}{l}\text { contrastive } \\
\text { topic non-topic }\end{array}$ & $\begin{array}{l}\text { shifting } \\
\text { topic non-topic }\end{array}$ & $\begin{array}{l}\text { constant } \\
\text { topic non-topic }\end{array}$ & $\begin{array}{l}\text { new } \\
\text { topic non-topic }\end{array}$ \\
\hline aber & $44 \% 6 \%$ & $12 \%-$ & $2 \%-$ & $18 \% 12 \%$ \\
auch & -- & $20 \% 40 \%$ & $16 \% 20 \%$ & $2 \% 2 \%$ \\
\hline
\end{tabular}

Let us consider some examples. A striking example is (16) which shows that even in cases with adversative aber topic shift is not always involved. It can be easily seen that (16) does not involve topic shift in any of the two intuitive senses considered in section 2.3 , since neither the aboutness nor the discourse topic changes: the entire discourse segment is about Hoffmann.

(16) Der Ingenieur Hoffmann $T_{1}$ lebt in einem Ort, wo es reichlich Kohle zu fördern und zu scheffeln gibt - ansonsten: nur Trunksucht, Inzest, geschundene Bergleute und freudlose Neureiche. Hoffmann ${ }_{T_{2}=T_{1}}$ aber hat reich geheiratet und das Geld seiner Frau gut angelegt. Er ist ein gemachter Mann. (Hamburger Morgenpost, 08.02.2009, S. 16; TAGESTIPP)

'The engineer Hoffmann lives at a place where there is plenty of coal to bank and amass - otherwise: only alcoholism, incest, oppressed miners and joyless

\footnotetext{
${ }^{20} \mathrm{An}$ interesting finding reflected in table 4 is the contrast between aber and auch with respect to their occurrence with aboutness topics and non-topics: whereas in the majority of cases aber is related to an aboutness topic, auch is most often related to a frame-setting topic or a non-topic and almost never to an aboutness topic. This has to do with the fact that post-initial auch does not combine with nominal constituents, as already pointed out above and shown in table 3 . This finding is however not of immediate relevance for the current study and will not be further assessed.
} 
nouveau-riches. Hoffmann however married a rich woman and invested his wife's money well. He is a self-made man.'

Moreover, even in shifting configurations with aber where the sentence topic is formally shifted per definition, the discourse topic is not always shifted. Consider again (15) where the sentence preceding the aber-sentence seems to involve wide focus. The propositional anaphor that occupies the pre-field in the aber-sentence should be construed as a shifting topic according to Breindl's definition, or as being in a shifting configuration according to my annotation. In terms of discourse topic, however, no shift is taking place: both sentences have as an overarching discourse topic the QUD "What does Katteker do?". The second sentence can be at most viewed as answering the subordinated QUD "Is that all he does?". It is a subordinated QUD since answering it also answers the superordinated QUD.

In the case of post-initial auch, it can also be shown that even in cases with shifting topic the discourse topic may remain constant. Consider (17) where the auch-sentence and the preceding sentence together answer the QUD "What did the author do all his life?"

(17) Ist das Leben ein Traum oder sind Träume das wirkliche Leben? In Handkes jüngstem Werk heißt es: "Zeit seines Lebens hatte der Autor über Nacht an einem Buch geschrieben. Und über Nacht auch hatte er es jeweils beendet. Bloß war das Buch dann am Morgen nicht mehr da." (Nürnberger Zeitung, 29.01.2008, S. 7; Peter Handkes "Morawische Nacht" Lebensreise auf dem Hausboot )

'Is life a dream or are dreams the real life? In Handke's most recent work it says: "All his life, the author has been writing a book over night. And each time, he has managed to finish it, likewise over night. Except that on the next morning, the book was not there anymore."

The auch-sentence introduces the subordinated QUD "What else did he do all his life over night?" but by no means changes the discourse topic.

Summing up, the results of my corpus study discussed so far suggest that post-initial particles are not sensitive to the topic-comment structure of the sentence. The corpus study falsifies both Breindl's topic association and topic shift assumptions: the pre-field constituent is often a non-topic; even when it is topic, it is not necessarily shifted, and this applies to both sentence and discourse topic.

What the results also show is that finding a proper generalization of the discourse function of post-initial particles should make reference to their semantics. Thus the comparison between the two particles on the basis of the results presented in table 5 clearly points in this directon: whereas the majority of cases of aber are found in a contrastive configuration, this configuration is not available for auch. Similarly, whereas aber is frequent with new topics, only one such case is attested for auch. Obviously, this has to do with the semantics of the two particles which is apparently complementary as argued in Sæbø (2003), according to whom aber and auch are topic-sensitive particles 
with a parallel semantics that can be formulated in terms of a presupposition that renders aber as the negative counterpart of auch (cf. section 4 for a more detailed description of this analysis of aber and auch; cf. also Winterstein and Zeevat, this issue, on auch). The fact that auch is seldom found in new-type configurations seems also to be related to the semantics of the particle, i.e. to the requirement it poses to the context that it should entail a type-identical alternative of the element associated with the particle (cf. section 4).

Current semantic theories of aber and auch argue convincingly that both these particles interact with/operate on the information structure of their host in a particular fashion (cf. e.g. Krifka 1999, Sæbø 2003, 2004, Umbach 2005). What they do not agree on is precisely which is the most relevant category when defining the interaction between particles and information structure. Moreover, no semantic account exists to my knowledge designed specifically to capture the post-initial occurrences of aber and auch.

On the other hand, the results of my corpus study clearly indicate that, at least with respect to their post-initial occurrences, aber and auch are sensitive to the focusbackground dimension in the following sense: The corpus data reveal a pattern such that the alleged pre-field associate of post-initial aber and auch may be either a topical or non-topical constituent, and in few cases this element was also focal. Non-focal constituents in the pre-field belong typically to the background, and in the cases when the pre-field element was focal, the rest of the sentence was backgrounded. I take this pattern as an indication that post-initial aber and auch are placed at the border between the background and the focus of the sentence in which they occur. ${ }^{21}$ Moreover, I suggest that the placement of these particles in post-initial position serves precisely this purpose, i.e. to single out the focus from the background. By doing this, the particles facilitate the interpretation of their host-sentence and its integration into existing discourse in a way that is determined by their semantics. ${ }^{22}$

Consequently, in the next section I look in more detail into the semantics of the individual particles in post-initial position in order to try and define the precise nature of their interaction with the focus-background structure.

\footnotetext{
${ }^{21}$ Steube (2000), among others, attributes the same function to sentence adverbials in the middle field, but see Frey's (2004) criticism. Frey (2004) argues instead that sentence adverbs in their base position in the middle-field mark the topic-comment boundary.

${ }^{22}$ As a matter of fact, Metrich (2003: 192) briefly notes that the discourse function of post-initially placed elements like aber, nämlich and wenigstens seems to be indicating the information-structural division of the sentence consisting of a thematic, "somehow given" pre-field element and the rest of the sentence representing "the actual core of the utterance". The position of the particles thus allows a direct access into the "communicative" structure of the sentence which otherwise must be deduced from the sentence and its context. This observation is very similar in spirit to my proposal, but although it is in my view basically correct, it remains merely impressionistic as it is not further substantiated by any sort of analysis.
} 


\section{The discourse function of post-initial aber and auch}

In this section, I present an alternative view on the discourse function of post-initial aber and auch in terms of marking the border between focus and background. I argue that this has different effects depending on the semantics of the particle: auch indicates that a focus alternative applies for the same background, whereas aber indicates that the denotation of the focus does not apply for some alternative of the background element or, conversely, that an alternative of the focus does not apply for the background. In addition, placing aber in post-initial position triggers in most cases the activation of alternatives to the pre-field constituent, whereas placing auch in post-initial position triggers the identification of the pre-field constituent as conveying information that is shared by both the proposition of the auch-sentence and the preceding sentence.

I start by taking a closer look at current theories of the semantics of additive and adversative particles, focussing on the question of how they relate to the task of finding an adequate description of the discourse function of post-initial aber and auch, as well as how they relate to the results of my corpus study. I moreover suggest how my findings can be integrated into these theories and how the theories can be refined and adapted to suit the data. I deal with the two particles in turn, starting with aber.

\subsection{The semantics of aber and its function in post-initial position}

The meaning of aber/but has been the subject of continuing debate at least over the past 40 years (for an overview, cf. e.g. Sæbø 2003 and Winterstein 2010).

Sæbø (2003) is one of the most sophisticated recent analyses of the semantics of aber which also deals with the post-initial use of the particle, albeit only marginally. I therefore take a closer look at it in order to assess the extent to which it is capable of explaining my data. I conclude that my data reveals a more complex picture and provide a more elaborate account of the discourse function of post-initial aber.

According to Sæbø (2003), the semantics of aber can be defined in a way that unifies the different readings of the word, in terms of a presupposition that makes reference to the contrastive topic of the aber-sentence and that gives rise to various further readings when the presupposition needs to be accommodated. Sæbø defines the meaning of aber in terms of semantic opposition. Semantic opposition is one of three types of contrast aber is a marker of, cf. (18-a). The other two types of contrast are usually referred to as denial of expectation (cf. (18-b)), where the aber-sentence suggests that it contradicts some expectation following from the preceding sentence, and concession (cf. (18-c)), where the first sentence counts as an argument pro and the aber-sentence as an argument contra some conclusion. ${ }^{23}$

(18) a. Weil er und seine Schwester evangelisch sind, der Vater aber katholisch , ... (Sæbø (2003: 1))

\footnotetext{
${ }^{23}$ For a more detailed description of the various contrast types see e.g. Lakoff (1971), Dascal and Katriel (1977), Blakemore (1989), Lagerwerf (1998), Umbach and Stede (1999), Lang (2004), Umbach (2005).
} 
'Because he and his sister are Protestants but their father is a Catholic,...'

b. Kamila und Ania sind katholisch, aber in die Kirche gehen sie nicht oft. (Sæbø (2003: 2))

'Kamila and Ania are Catholics, but they do not go to Church frequently.'

c. Clever genug ist er, aber zu faul. (Sæbø (2003: 2))

'He is clever enough, but hes too lazy.'

Sæbø formulates a semantics for aber in terms of the presupposition that the result of substituting the contrastive topic of the aber-sentence by an alternative is negated by the context (or, in other words, that the context entails the negation of the result of this substitution), formally: $\sigma \llbracket \phi$ aber $\rrbracket$ iff $\sigma \models \neg \phi[T(\phi) / \alpha]$ for some alternative $\alpha$ and $\sigma \llbracket \phi \rrbracket \tau$ (to be read as: a sentence of the form ' $\phi$ aber' updates the context $\sigma$ to a context $\tau$ iff $\sigma$ entails the negation of $\phi$ where the contrastive topic of $\phi$ is substituted by some alternative, and $\sigma$ is updated by $\phi)$. The way the definition works is illustrated by (19).

(19) Für kleine Betriebe hält sich der Schaden noch in Grenzen; für mittlere wird er aber allmählich ruinös. (Sæbø (2003: 5))

'For small companies, the harm is yet limited; for intermediate-size companies, however, it is becoming ruinous.'

$\neg$ (for intermediate-size companies the harm is ruinous)[intermediate-size/small]

$\neg$ (for small companies the harm is ruinous)

Here, the aber-presupposition can be verified: in the negated aber-sentence, we replace its contrastive topic mittlere for an alternative, here kleine, and get that the harm for small companies is not ruinous. This is entailed by the preceding sentence which asserts that the harm is limited.

Sæbø (2003: 5) deals briefly with post-initial aber pointing out that in this position, the particle identifies the pre-field element as one "for which the context should provide an alternative and contradict the result of substituting it". His aber-definition thus accounts in a straightforward way for cases where post-initial aber is involved in what I called the contrastive discourse configuration. However, as Sæbø (2003: 10) points out, cases abound in which no obvious topic alternative is present in the context in the form of a specific overt expression and where the relevant contrast must be reconstructed. The examples Sæbø discusses in connection with these cases do not involve post-initial aber. However, it seems that these are precisely the cases which best illustrate the role post-initial aber plays in discourse. They involve post-initial aber in the discourse configurations of type shifting, constant and new that I defined in section 3.1. Consider again (16), repeated as (20), where the pre-field element in the aber-sentence is aboutness topic and is involved in a constant type discourse configuration.

(20) Der Ingenieur Hoffmann lebt in einem Ort, wo es reichlich Kohle zu fördern und zu scheffeln gibt - ansonsten: nur Trunksucht, Inzest, geschundene Bergleute und freudlose Neureiche. Hoffmann aber hat reich geheiratet und das Geld seiner Frau gut angelegt. Er ist ein gemachter Mann. 
According to Sæbø, in order to reconstruct the contrast, one first has to identify the topic-alternative pair. In (20), the topic of the aber-sentence is Hoffmann, and a possible alternative would be the oppressed miners or the joyless nouveau-riches. But in (20), the context does not entail that other inhabitants of Hoffmann's village have married rich. In order to construe Hoffmann and the other people in the village as alternatives, one has to come up with a relevant parallel between them (i.e. one should think of them as having a Common Integrator in the sense of Lang 1984). Identifying two expressions $\mathrm{a}$ and $\mathrm{b}$ as alternatives is a complex process. On the one hand, one has to accommodate that $\mathrm{a}$ and $\mathrm{b}$ are alternatives. And on the other hand, accommodating that $\mathrm{a}$ and $\mathrm{b}$ are alternatives involves making "conversational sense" of the alternativeness relation between them, i.e. figuring out how this alternativeness relation is relevant, which is a process that triggers conversational implicatures based on the Maxim of Relevance. Thus Sæbø suggests that the relations of concession and denial of expectation that are associated with aber are a product of such a pragmatic process: "The assumption that it is relevant that $\mathrm{a}$ and $\mathrm{b}$ are alternatives can be justified as, inter alia: a gives reason to assume $\mathrm{b}$, a and $\mathrm{b}$ pull in the same direction in some respect, both a and $\mathrm{b}$ are good, or bad." (Sæbø 2003: 11). Reconstructing the relevant contrast in (20) involves a parallel between Hofmann and the other inhabitants of his village in terms of e.g. the property of "doing well". In fact, the parallel on which the contrast is based is explicated in the follow-up sentence Er ist ein gemachter Mann.

Thus, applying Sæbø's account of aber to its post-initial uses leads to the conclusion that the role of post-initial aber in discourse can be formulated in terms of indicating relevant alternatives and thus facilitating the reconstruction of the relevant contrast. (This is also compatible with Metrich and Courdier's general stance.) This role of postinitial aber becomes more apparent when we compare (21-a) with the version of the sentence where aber is in the null-position (21-b) and in the middle field (21-c): the intended contrast between the topic of the aber-sentence and the individuals mentioned in the preceding sentence seems harder to reconstruct in (21-b) and (21-c).

(21) Der Ingenieur Hoffmann lebt in einem Ort, wo es reichlich Kohle zu fördern und zu scheffeln gibt - ansonsten: nur Trunksucht, Inzest, geschundene Bergleute und freudlose Neureiche.

a. Hoffmann aber hat reich geheiratet und das Geld seiner Frau gut angelegt. Er ist ein gemachter Mann.

b. Aber Hoffmann hat reich geheiratet und das Geld seiner Frau gut angelegt. Er ist ein gemachter Mann.

c. Hoffmann hat aber reich geheiratet und das Geld seiner Frau gut angelegt. Er ist ein gemachter Mann.

The explanation provided in Sæbø's account is that placing aber in post-initial position facilitates the identification of an appropriate alternative of the pre-field element that is necessary in order to reconstruct the intended contrast. In comparison, none of the other two placements seems to do this unambiguously. In fact, (21-b) represents a less coherent discourse than (21-a). When aber is in the two other positions, it is not obvious at all 
that the contrast involves an alternative to the pre-field element, i.e. that an alternative to Hoffmann should be identified.

On the other hand, although compatible with the general approach in Sæbø, my data reveals a more complex and fine-grained picture of the way post-initial aber facilitates discourse interpretation. As I will show in the remainder of this section, a more appropriate generalization that accounts for my data is that post-initial aber marks the boundary between the background part (usually to its left) and the focus part (usually to its right) of its host-sentence. By doing that, it facilitates interpretation by unambiguously identifying alternatives to the (new-information) focus, and in most cases also by signaling the need for identifying alternatives to the element in the pre-field. Post-initial aber indicates that the material contained in the focus doesn't apply for an alternative of the pre-field element, where the pre-field element belongs to the background, or that, conversely, an alternative of the focus does not apply for the element in the pre-field/background. ${ }^{24}$

There are two points to be made here in order to motivate this proposal.

(i) First of all, recall that Sæbø (2003) argues that aber in general associates with the contrastive topic of its host, and that post-initial aber identifies the pre-field constituent as "the topic" for which the context "should provide an alternative and contradict the result of substituting it". ${ }^{25}$ My data suggests that the pre-field element is far from always contrastive per se, i.e. by virtue of accent or obvious alternatives in the preceding context. Nevertheless, in most of the cases it is construed in terms of contrastive topic proper, indicating the presence of salient alternatives and giving rise to inferences to the effect that the predication of the sentence does not apply for these alternatives (cf. also the discussion of contrastive topics in section 3.1). In my view, it is the post-initial placement of aber that makes the pre-field constituent contrastive in these cases: it indicates that alternatives of the pre-field element exist in the context. In addition, by

\footnotetext{
${ }^{24}$ This way of looking at the interpretation of aber represents a reversed version of Sæb $\varnothing$ 's account where the semantics of aber is formulated in terms of the "topic" not applying to a focus alternative. On the other hand, Sæbø (2003: 10) makes it clear that his analysis applies in both directions (but see Winterstein and Zeevat, this issue, on some cases of asymmetry of aber/however-sentences). We can look the same way at cases with genuine contrastive topics like (ii) below, where the inference can be derived that John does not play the piano. This is plausible since the discourse would not be felicitous if we knew that John plays the piano. This analysis is also compatible with Umbach (2005) who argues that aber/but-sentences imply the negation of some QUD. In (ii), the QUD is "Does Paul do the same as John?" which is negated by the aber-sentence. On my account, the aber-sentence implies "John does not do the same as Paul" rather than "Paul does not do the same as John", but the effect is the same.

(ii) John spielt violine, Paul aber spielt Klavier. ('John plays violine. Paul, however, plays the piano.')

${ }^{25}$ It should be noted that Sæbø uses the term contrastive topic in the rather wide sense of an expression that gives rise to alternatives, and his "contrastive topic" is in some cases used to refer to the sentence focus. Thus Sæbø (2003: 10) argues that the topic-alternative pair for the sentence Die Waldwege sind steil, aber nicht lang. ('The forest paths are steep but not long.) consists of the adjectives steil and lang. Normally, one would construe die Waldwege as the aboutness topic and the two adjectives as foci. Besides, in the cases of contrastive topics proper that I discussed in section 3.1 and that contain two pairs of alternative-evoking expressions, one in the pre-field and one in the middle field, verifying the aber-presupposition succeeds when one of these expressions, no matter whether in the pre-field or in the middle-field, is identified as one for which the context provides alternatives.
} 
activating a set of contextually salient alternatives, post-initial aber seems to mark the pre-field element as belonging to the background, since it is derivable from this salient set of alternatives. ${ }^{26}$ As a result, post-initial aber induces a pairwise contrast between the backgrounded pre-field element and an alternative and the focus and its negation, to the effect that it is suggested that the focus does not apply for an alternative of the pre-field/background element. ${ }^{27}$ The ability of post-initial aber to elicit alternatives of the pre-field element can be demonstrated for cases where post-initial aber is involved in discourse configurations of type constant and new. One such case is (20) where the pre-field element Hoffmann is not a priori contrastive, since it can be shown that by removing aber, the contrast between Hoffmann and the other inhabitants is not preserved. A similar case is (22-a) where a comparison to middle-field aber in (22-b) shows that whereas post-initial aber elicits alternatives to the background, middle-field aber does not necessarily do so.

a. [Sesshaftigkeit $]_{T_{1}}$ bedeutete ihm mehr als Pilgerschaft und freiwilliges Exil. [Sesshaftigkeit $]_{T_{2}=T_{1}}$ aber setzt Besitz voraus.

'Settledness meant more to him than pilgrimage and voluntary exile. Settledness however presupposes possession.'

b. Sesshaftigkeit bedeutete ihm mehr als Pilgerschaft und freiwilliges Exil. Aber Sesshaftigkeit setzt Besitz voraus.

Intuitively, (22-a) suggests that the predication of the aber-sentence, i.e. the material to the right of the particle, does not apply for an alternative of the pre-field element, i.e. alternatives of "settledness" do not presuppose possession. ${ }^{28}$ In contrast, (22-b) does not immediately give rise to such an inference. The same applies also to cases involving shifting type configuration, as in (4) where the alternative to "he" is not "we" but "others" and the aber-sentence gives rise to the inference "others would be persuaded". Further evidence provides the comparison between (23-a) and (23-b). In (23-a), the wide focus generates alternatives to "go for a walk" thus guiding interpretation towards the type of contrast known as denial of expectation: normally, we do not go for a walk but do something else, e.g. stay at home and drink tea. In (23-b), we can derive a different contrast in terms of the inference "others would not go for a walk".

a. Es regnet, wir gehen aber spazieren.

'It is raining, we are however going for a walk.'

\footnotetext{
${ }^{26}$ It seems further that in these cases aber is obligatory in the sense that its presence is necessary in order to make sense of the discourse in the intended way (but not necessarily in the post-initial position).

${ }^{27}$ This fact is also noticed by Breindl who argues that only the interpretation of pairwise contrast is possible with post-initial aber. Metrich and Courdier argue in contrast that post-initial aber may also indicate other contrast relations. This seems to be correct, see the discussion of example (24) below.

${ }^{28}$ The interpretation involves accommodating the alternativeness relation between settledness and pilgrimage along a relevant parallel in terms of the property of presupposing possession: since pilgrimage does not presuppose possession, it must be an alternative. The property of presupposing possession is the relevant parallel based on which pilgrimage is identified as the alternative of settledness, and the inference that pilgrimage does not presuppose possession is information that is accommodated in the process of attempting to verify the aber-presupposition.
} 
b. Es regnet, wir aber gehen spazieren.

'It is raining, we however are going for a walk.'

Cases of post-initial aber in configurations of type new provide even stronger evidence for this assumption, since there post-initial aber is capable of eliciting alternatives to the pre-field element that are non-existent in the preceding context, as well as to mark the pre-field constituent as belonging to the background. This is illustrated by cases like (11), where the aber-sentence indicates that the event it introduces did not take place at some alternative point in time. Without an adversative element like aber, cases like (21-a), (22-a), (4) and (11) loose their contrastive interpretation and become elaboration or narration discourses (or the discourse becomes incoherent). On the other hand, genuinely contrastive topics such as (5-a) and (5-b) do not need additional marking. They are already indicated as such by their parallel syntactic structure (and their specific intonational contour).

(ii) The second point to be made is that indicating alternatives to the pre-field element is not the only function of post-initial aber, since in some cases involving shifting and constant configurations there is no plausible interpretation on which the pre-field element is contrasted with some element in the preceding discourse. Rather than giving rise to alternatives of the pre-field constituent, aber associates with the rest of the sentence which is (new-information) focus, indicating that a focus alternative (explicit or reconstructed as an implicature in the process of identifying the focus alternative) does not apply for the background. This point is illustrated by (24).

Es war ja zum Glück nur der erste Test des neuen Jahres. Der aber ging gründlich in die Hose: ... (Hamburger Morgenpost, 13.01.2009, S. 35; 24 - gegen Lautern geht halt nix)

'It was fortunately just the first test of the new year. However, it was a complete flop.'

Here, aber does not associate with the pre-field element in terms of eliciting alternatives to it, i.e. aber does not primarily elicit alternatives to der erste Test. What the discourse conveys can be formulated as "being just the first test opens up the possibility for eventual success, and it being a complete flop reduces the chances for eventual success". Thus an alternativeness relation is established between the focus, being a complete flop, and the alternative, being the first of the year, whose relevance is ensured by a parallel in terms of having chances for eventual success.

Cases like (24) suggest that what is constant for all occurrences of post-initial aber is its association with the (new-information) focus, usually to the right of the particle, indicating that an alternative of the focus does not apply to the background constituent, and that post-initial aber (and arguably aber in general, cf. Umbach 2005) is more adequately accounted for in terms of association with the (new information) focus, rather than the contrastive topic. In fact, this view is not incompatible with Sæbø, since in many of the cases discussed by him, the alternative-evoking expression involved in the interpretation of the aber-sentence belongs to the (new-information) focus of the aber- 
sentence (cf. the discussion of Sæbø's notion of contrastive topic in fn. 25). What is special about the post-initial position of aber is that it separates the focus from the background, thus clearly identifying the expression whose alternatives are relevant for the interpretation of the sentence. This is illustrated by a comparison between (25-a) and $(25-\mathrm{b})$.

a. Sesshaftigkeit bedeutete ihm mehr als Pilgerschaft und freiwilliges Exil. Sesshaftigkeit aber setzt Besitz voraus.

b. Sesshaftigkeit bedeutete ihm mehr als Pilgerschaft und freiwilliges Exil. Sesshaftigkeit setzt aber Besitz voraus.

In (25-b), the focus is narrow and involves just the object "Besitz", in (25-a) it comprises the entire VP. This has the following effect on the interpretation of the discourse: Since in the case of post-initial aber focus is broad and comprises the entire VP, the alternative is construed as the negation of the focus. ${ }^{29}$ As a consequence of that, (25-a) suggests that pilgrimage does not involve possession. On the other hand, middle-field aber in (25-b) associates rather with narrow focus, which generates a different alternative, suggesting rather something weaker - that pilgrimage involves something different than possession. From this of course the more general proposition that pilgrimage does not involve possession can be derived, but this is a cognitive detour. ${ }^{30}$

Summing up, the main result of the discussion in this subsection is that a complete story of the discourse function of post-initial aber needs to take into account both its interaction with the pre-field element and with the focus, an interaction that is enabled by its placement. The way in which post-initial aber guides the search for the relevant contrast involves both sides of this interaction. On the one hand it associates with the focus on its right, and on the other it identifies the pre-field element as the background of the sentence, mostly in terms of it belonging to a contextually salient set of alternatives. In doing that, post-initial aber identifies relevant alternatives that participate in the interpretation of the sentence. In comparison, when aber is in the null position, or in the middle field, it does not mark the focus-background partitioning of the sentence in which it occurs but only provides the general instruction that the discourse has to be interpreted in terms of contrast of some sort. ${ }^{31}$ When aber is placed in the post-initial position, it serves as a structural device for partitioning the sentence into background and focus and thus for identifying relevant alternatives that participate in discourse interpretation. When it is placed in its other positions, the lack of structural means

\footnotetext{
${ }^{29}$ In cases like (16), where the focus alternative has to be identified first, the starting point for verifying the presupposition is the sentence modified in accordance to the relevant parallel, here Hoffmann aber geht es gut ('Hoffmann is doing well'), and from here both the focus alternative and the alternative to the pre-field can be identified: the others are not doing well.

${ }^{30}$ The post-initial position has also certain effects on further discourse: whereas in (22-a) the discourse may continue without further specifying what pilgrimage involves, (25-b) triggers expectations towards specifying what that other thing is that is not possession.

${ }^{31}$ The idea that discourse markers provide processing instructions to the hearer is not new and has been developed in relevance-theoretical work where a distinction has been made between conceptual and procedural meaning, discourse connectors belonging to the second category (cf. Blakemore 2002).
} 
for indicating the focus-background partitioning in written texts lacking prosodic clues may lead to several coexistent interpretations. Thus placing aber in post-initial position seems to have a disambiguating effect. This assumption is supported by the fact that constructions with post-initial particles are typical for and more frequent in written than in spoken discourses.

\subsection{The semantics of auch and its function in post-initial position}

As in the case of aber, the semantics of auch turns out to be instructive when trying to define its function in the post-initial position. The semantics of auch/too is usually described in terms of it operating on the set of alternatives activated by alternative evoking expressions in the auch-sentence, which is also the reason for calling it a "focus particle" (cf. Rooth 1992, König 1991, 1993, Krifka 1992, 1999). It is defined in terms of it introducing a presupposition indicating that a type-identical alternative to the constituent it is associated with, called the associate, is already part of the context (cf. Gazdar 1979, Krifka 1999, Sæbø 2003, 2004, but see Winterstein and Zeevat, this issue for various problems with the presuppositional account of auch/too). To give an example, (26), where auch is placed in the pre-field preposed to the pre-field constituent, here the focal element dort, indicates that there are other places where the director could find what he was looking for. ${ }^{32}$

(26) Eine davon hielt Einzug in das vor vier Jahren herausgegebene Buch "17 Kurze. Kurzgeschichten aus dem Netz" von Mirko Perschke, Initiator des Internet-Projektes. Auch dort wurde Regisseur Ulf H. Czellnik fündig.

'One of them found its way into the book "17 short. Short stories from the net" that was published four years ago by Mirco Perschke, the internet project's initiator. This was another place where the director Ulf H. Czellnik found what he was looking for.'

In the middle-field, auch behaves in a similar fashion in that it associates with an alternative-evoking expression. There are several positional and intonational possibilities: unaccented in front of the subject which is in turn accented (27-a), or in front of the non-finite verb, accented (27-b) or unaccented (27-c). ${ }^{33}$

(27) a. Eine davon hielt Einzug in das vor vier Jahren herausgegebene Buch "17 Kurze. Kurzgeschichten aus dem Netz" von Mirko Perschke, Initiator des Internet-Projektes. Dort wurde auch Regisseur Ulf H. Czellnik fündig.

b. Eine davon hielt Einzug in das vor vier Jahren herausgegebene Buch "17 Kurze. Kurzgeschichten aus dem Netz" von Mirko Perschke, Initiator des Internet-Projektes. Dort wurde Regisseur Ulf H. Czellnik AUCH fündig.

c. Eine davon hielt Einzug in das vor vier Jahren herausgegebene Buch "17 Kurze. Kurzgeschichten aus dem Netz" von Mirko Perschke, Initiator des

\footnotetext{
${ }^{32}$ This is a modified version of the authentic example in (29). The local context of (26) does not satisfy the auch-presupposition but this is not relevant for the sake of the argument.

${ }^{33}$ These are further modifications of the corpus example in (29).
} 
Internet-Projektes. Dort wurde Regisseur Ulf H. Czellnik auch FÜNDIG.

In both (27-a) and (27-b), auch associates with the focussed subject in the middle field that evokes alternatives to "Regisseur Ulf H. Czellnik". The unaccented use in the middle field (27-c) may be accompanied by narrow focus on the element to the right that represents the right sentence bracket indicating salient alternatives to the action denoted by the non-finite verb form. The other possibility is that auch associates with the broad focus comprising the entire sentence modulo the pre-field element.

A comprehensive syntactic analysis of the distribution of auch in its two prosodic variants, accented and unaccented, as well as an analysis of the relation between their syntax, semantics and information structure is presented in Reis and Rosengren (1997). ${ }^{34}$ Unfortunately, Reis and Rosengren (and, in fact, all other previous work on auch) do not consider post-initial auch a grammatically viable option.

Concerning the semantics of auch, I will focus in what follows on $\operatorname{Srb} \varnothing(2003,2004)$ where an analysis of auch parallel to aber is suggested. Following Krifka (1999), Sæbø argues that auch/too associates with the contrastive topic of the auch-sentence and suggests that aber is to be analyzed as the negative counterpart of auch: auch presupposes that the context entails the result of replacing the (contrastive) topic of the sentence by an alternative. (Formally: $\sigma \llbracket \phi$ aber $\rrbracket \tau$ iff $\sigma \models \phi[T(\phi) / \alpha]$ for some alternative $\alpha$ and $\sigma \llbracket \phi \rrbracket \tau$. To be read as: a sentence of the form ' $\phi$ aber' updates the context $\sigma$ to a context $\tau$ iff $\sigma$ entails $\phi$ where the contrastive topic of $\phi$ is substituted by some alternative, and $\sigma$ is updated by $\phi$.) (28) illustrates how this definition works.

(28) Für kleine Betriebe hält sich der Schaden in Grenzen; für mittlere bleibt er auch gering. ${ }^{35}$

'For small companies, the harm is limited; for intermediate-size companies, it also remains marginal.'

(for intermediate-size companies the harm remains marginal) [intermediate-size/small] (for small companies the harm remains marginal)

Here, the auch-presupposition can be verified: in the auch-sentence, we replace its contrastive topic mittlere for an alternative, here kleine, and get that the harm for small companies remains marginal. This is entailed by the preceding sentence which asserts that the harm is limited.

Sæbø (2004) defines contrastive topic as accented topic and observes that whereas the associate of auch is always the contrastive topic of the auch-sentence, its presupposed alternative need not be accented topic, and it may be even covert.

Turning to the post-initial cases (which are not considered by Sæbø), my data suggest no association with contrastive topic. The pre-field element is never a contrastive topic in any of the senses discussed in section 2.3 , and the material to the right of the particle

\footnotetext{
${ }^{34}$ Reis and Rosengren (1997) suggest that auch, in addition to its presupposition (or conventional implicature in their terms) in fact contributes a non-presuppositional, truth-functionally relevant meaning element they call ADD.

${ }^{35}$ This is a modification of Sæbø's (2003) original aber-example discussed under (19) above.
} 
is always (new-information) focus. A comparison between post-initial auch and its other positional variants shows that post-initial auch has the same property of associating with alternative-evoking expressions and operating on alternatives. Post-initial auch however always associates with the focus on its right. Consider (29).

(29) Eine davon [hielt Einzug in das vor vier Jahren herausgegebene Buch "17 Kurze. Kurzgeschichten aus dem Netz" von Mirko Perschke, Initiator des Internet-Projektes $]_{F}$. Dort auch [wurde Regisseur Ulf H. Czellnik fündig $]_{F}$. (Braunschweiger Zeitung, 28.01.2006; Kreativer Kopf für Kurzfilme aus Peine) 'One of them found its way into the book "17 short. Short stories from the net" that was published four years ago by Mirco Perschke, the internet project's initiator. This was also the place where the director Ulf H. Czellnik found what he was looking for.'

Intuitively, the auch-sentence in (29) indicates that some further event has occurred at the place denoted by the pre-field constituent. This means that the entire material to the right of the particle, denoting the event of the director finding what he was looking for, is the element that gives rise to the alternative event. The pre-field constituent that anaphorically refers to the local PP in the preceding sentence, denotes the place at which both events occur.

The situation is similar in (30). When it is positioned in the pre-field together with a focussed element in its scope, auch indicates that there are further reasons for the eventuality described in the sentence, cf. (30-b). In contrast, (30-a) where auch is in post-initial position, indicates something fundamentally different, namely that there are further consequences of the eventuality described in the sentence.

(30) Wayne McGregor erschliesst dem Tanz neue Formen und neue Themen, wie sie einer Gegenwart entsprechen, die zunehmend von neuen Erkenntnissen und vom Computer geprägt wird. Deshalb ist er gefragt als Choreograph - sogar in Paris und von traditionellen englischen Bühnen wie dem Sadler's Well Theatre.

'Wayne McGregor opens up new dance forms and themes that correspond to a present time increasingly dominated by new insights and computers. Therefore is he sought-after as a choreographer - even in Paris and by traditional English theaters such as the Sadler's Well Theatre.'

a. Darum auch haben bereits "Die Welt" und die "Süddeutsche Zeitung" über den Auftritt von Wayne McGregors Random Dance innerhalb der Movimentos-Festwochen ausführlich berichtet.(Braunschweiger Zeitung, 02.05.2008;

Tanz im Takt von Gehirnströmungen und Lauf der Windhunde)

'This is also why/For the same reason "Die Welt" and the "Süddeutsche Zeitung" already reported in detail on Wayne McGregors Random Dance's performance at the Movimentos-festival.'

b. Auch DARUM haben bereits "Die Welt" und die "Süddeutsche Zeitung" über den Auftritt von Wayne McGregors Random Dance innerhalb der Movimentos-Festwochen ausführlich berichtet. 
'This is another reason why "Die Welt" and the "Süddeutsche Zeitung" already reported in detail on Wayne McGregors Random Dance's performance at the Movimentos-festival.'

In (30-b), the causal adverbial darum is accented, and the alternatives that the accent evokes are further causes for the event described in the sentence. The rest of the sentence is backgrounded. In (30-a), darum is not focussed but backgrounded, and the focussed part is the rest of the sentence to the right of post-initial auch. Auch associates with this focal part of the sentence which denotes an event. In (30-a), the sentence answers the QUD "What else happened for that reason?", whereas (30-b) answers the QUD "What other reasons were there for the newspapers to write about the performance?".

What (29) and (30) show is that in terms of information structure, the material to the right of the particle represents the new-information focus of the sentence. When preposed in the pre-field, auch designates the denotation of the focussed element as the aspect of the event that differs from the alternative event. Auch placed in the middle-field seems to allow for both interpretations when no prosodic clues are there to disambiguate between the two possible readings. When placed in post-initial position, auch designates the entity denoted by the pre-field element as the aspect of the event expressed by the auch-sentence that it shares with the event described in the preceding sentence, i.e. as part of the background of the auch-sentence. This is supported by the results of my corpus study presented in table 5 where in the majority of cases, the pre-field constituent was in a shifting or constant configuration. The two exceptions where the pre-field constituent is new to discourse only confirm this rule. Consider (31) where the presence of the attitude adverb leider in the pre-field suggests that the event described in the preceding sentence is also regrettable:

(31) Man hat vielleicht oft das Gefühl, dass das Hören von Klassik das Abarbeiten einer Schuld ist. Leider auch hat das symphonische Klangbild in der heutigen Unterhaltungsmusik keine nennenswerte Rolle mehr. (Mannheimer Morgen, 16.05.2008, S. 26; "Klavierlehrer vermittelte mir Freude an Musik")

'Perhaps one has often the feeling that listening to classical music is like working off a debt. Likewise unfortunately, the symphonic sound does not play a noteworthy role in present-day light music anymore.'

Cases like (31) provide even stronger evidence for the interaction of post-initial auch with the pre-field constituent. In (31), it is the presence of auch in post-initial position that leads to interpreting the pre-field element as denoting an aspect of the event described by the auch-sentence that it shares with the event described in the preceding sentence, since nothing in the preceding context seems to suggest this. In other words, this is information that must be accommodated and that leads to interpreting the pre-field constituent as belonging to the background of the sentence.

I suggest therefore that post-initial auch serves to unambiguously identify the prefield constituent as the background of the sentence and the rest of the sentence as 
the focus ${ }^{36}$ thus marking the border between background and focus. By doing this it identifies unambiguously the element for which alternatives exist in the context. It announces for the listener that the rest of the sentence is material for which the context provides a type-identical alternative and which shares with this alternative one common element, the one denoted by the pre-field constituent. In addition, post-initial auch also interacts with the background constituent, though in a different way, by indicating that the information it denotes is shared between the auch-proposition and the proposition expressed by the preceding sentence.

In this way, auch has a function similar to post-initial aber in that it facilitates the interpretation of the sentence and its integration into existing discourse. Additionally, the placement to the right of the pre-field constituent seems to be the only positional possibility for auch for unambiguously expressing the intended content, since the placement in the middle field is ambiguous without intonation.

The idea that post-initial auch marks the division into background or old information and (new-information) focus is reminiscent of a distinction made in Reis and Rosengren's (1997) account of auch. Reis and Rosengren argue that auch in general divides the auchproposition into its associate, the added constituent (AC, i.e. the "variable material in the proposition of the auch-clause compared with some other proposition in the context"), and the rest of the proposition that is the material common to both propositions, called the identical material (ID). In their view, auch gives rise to the (conventional) implicature that the context contains a proposition $\mathrm{q}$ to which $\mathrm{p}$ is added such that $\mathrm{q}, \mathrm{p}$ "are partially alike and partially different", i.e. have the same AC/ID division. They point out (p. 275) that in the case of unaccented auch, there is a systematic covariation between focus-background, rheme-theme and AC-ID division in terms of a correspondence between focus, rheme and $\mathrm{AC}$ on the one hand and background, theme and ID on the other. ${ }^{37}$ Thus, my findings on post-initial auch (which is unaccented) support Reis and Rosengren's findings on unaccented auch in its other positions. ${ }^{38}$ It should be noted here that their account is able to capture cases like (35), unlike accounts like Sæbø $(2003,2004)$ which, albeit similar in spirit, do not make reference to the AC/ID division but only consider the AC part of it. On the other hand, my account of postinitial auch is compatible with Sæbø's general approach, while suggesting a refinement in terms of two main observations: (i) that auch operates on alternatives made salient by an alternative-evoking expression that need not be contrastive topic, and (ii) that it in addition designates the pre-field element as belonging to the background.

\footnotetext{
${ }^{36}$ Although no such cases were attested, it is conceivable that the focus-background partitioning could be reversed. This would not present a problem for this account, I believe.

${ }^{37}$ Reis and Rosengren argue that in the case of accented auch, the AC/ID-division is not determined by focus but by comparing the auch-clause with the proposition it is added to. They further (1997: 289) point out in connection with accented auch that there is no 1:1 correspondence between the added constituent and rhematic material, since there are cases where AC may comprise thematic material.

${ }^{38} \mathrm{But}$ note that they have a different concept of what focus-background is than I; I conflate it with theme-rheme.
} 


\subsection{Upshot}

I argued that the discourse function of post-initial aber and auch can best be described in terms of marking the border between the (new-information) focus and the background of their host-sentence, thus unambiguously indicating the focus-background division of the sentence and identifying alternative-generating expressions with which the particles semantically interact. In this way, their placement facilitates the interpretation of the sentence and its relation to existing discourse. In this position, both particles trigger presuppositions that interact with the focus-background structure of the sentence and involve relations between background and focus and their alternatives: auch indicates that a focus alternative applies for the same background, aber that the denotation of the focus does not apply for some alternative of the background element, or, conversely, that an alternative of the focus does not apply for the background. In particular, post-initial aber and auch interact with both the pre-field element, which is usually backgrounded, and the rest of the sentence to their right, which is usually the alternative-evoking newinformation focus of the sentence. On the one hand, aber and auch associate with the focus in that they operate on alternatives evoked by that part of the sentence that hosts them. This is also the interaction that is captured by the existing semantic accounts of aber and auch. On the other hand, both aber and auch enter a semantic relation to the pre-field element as well: auch by indicating that the pre-field element represents the shared background for the two events described by the auch-sentence and the preceding context, and aber by indicating that the pre-field element belongs to the background, in most cases in terms of it belonging to a contextually salient set of alternatives. Integrating the post-initial uses of aber and auch into existing approaches to their meaning requires therefore an account of both interactions involving the entire focus-background structure of the sentence. ${ }^{39}$

The comparison of the post-initial particles with their other positional variants suggests that their placement has a disambiguating effect. This is not surprising when one considers that this placement is more typical for written than for oral discourses - the lack of disambiguation mechanisms such as intonation is compensated for by structure. Thus my account suggests that placing particles in the post-initial position in German may be a means for avoiding ambiguity by exploiting existing structural options. This means also that languages may differ with respect to the means they provide for marking relations in discourse.

Disambiguation may also be at least part of the explanation for the distributional restrictions of German connectors: the need for disambiguation makes the post-initial position available for aber and auch, whereas other additive and adversative connectors do not have this pressure to take advantage of alternative structural options. For instance, ausserdem ('furthermore') is not focus-sensitive, it is anaphoric and always implies addition of the proposition expressed by its host to the body of information

\footnotetext{
${ }^{39}$ Appropriate frameworks would be the theory of structured meanings developed in von Stechow (1990) and Krifka (1992) and the version of DRT that accounts for the focus-background division of the sentence presented in Kamp (2004). The latter was already applied to aber in Karagjosova (2009), however without considering its post-initial uses.
} 
currently accumulated in discourse. Similarly, doch ('though') in the middle field marks correction which is a more specific discourse relation than the one marked by its adversative variant in the null-position, which rules out ambiguity between these positional variants and makes additional structural marking unnecessary.

\section{Conclusions and outlook}

I presented a corpus-based analysis of post-initial aber and auch showing that aber and auch in this position mark the border between the background and the focus of their host. By doing this, they essentially contribute to identifying relevant alternatives involved in focus interpretation and discourse interpretation in general, in a way that is related to their semantics. Their placement in this position facilitates interpretation by providing processing instructions to the reader/hearer and by ruling out ambiguities. My study falsifies existing assumptions of topic-association and topic-shift put forward in previous work.

The results of this study contribute to the better understanding of constructions with post-initial particles in several respects. First of all, it sheds new light on the discourse function of post-initial connectors like aber and auch. Second, it provides an explanation of the relation between the discourse function and the semantics of these particles, and contributes thus also to the better understanding of adversative and additive connectors, in discussing new data and showing how it can be integrated into existing semantic theories of aber and auch.

Third, the results of my analysis of the data have relevance for the question of the syntactic status of post-initial particles like aber and auch. The way post-initial auch relates to the pre-field element is essentially different from pre-posed auch in the prefield. Pre-posed auch seems to relate both syntactically and focus-semantically to the pre-field element, although it has been claimed in Büring and Hartmann (2001) that auch does not attach to the pre-field element but to the entire clause or CP in syntactic terms; in fact, such an analysis does not do justice to post-initial auch either. In contrast, post-initial auch does not associate with the pre-field element in terms of focus but still interacts with it semantically by marking the "sameness" of the pre-field element with respect to the preceding context. Similarly, whereas aber in its other positions seems to behave more like a sentence adverbial taking scope over the entire sentence, postinitial aber associates semantically not only with the focus to its right but also with the pre-field element, by marking the "distinctness" of the pre-field element, i.e. by indicating that the pre-field element has a salient alternative. These observations seem to call for an analysis in the spirit of Reis and Rosengren's (1997) analysis of auch, where post-initial aber and auch are XPs adjoining to the pre-field XP (with the combinatorial restrictions for auch mentioned in section 3) while having semantic scope over the rest of the proposition in terms of association with focus. Incorporating these observations into a syntactic account of the two particles remains however outside the scope of the present work.

Finally, the study also contributes to the understanding of the nature of the dis- 
tributional constraints of German connectors. In addition, the observation that aber and auch exploit both information structure and syntactic structure in contributing to the interpretation of sentences in discourse shows that there may be language-specific aspects to this issue that also need to be taken into account when looking at similar particles in other languages.

More work needs to be done with respect to integrating the findings presented here into full-fledged syntactic and semantic accounts of the two particles that take into consideration the post-initial uses. Future work will also show whether the generalization of the function of post-initial aber and auch applies to further particles such as e.g. nämlich, as well as whether their distributional restrictions can be explained by the disambiguation hypothesis suggested above. This requires a considerable amount of further research on the distributional constraints of a larger group of discourse particles.

Acknowledgements I would like to thank the members of the project Meaning and understanding across languages at the Centre for Advanced Study (CAS), Oslo, as well as the participants of the Adversative Workshop conducted at CAS, for insightful discussions on the topic of the paper. I am especially grateful to Cathrine Fabricius-Hansen, Katja Jasinskaja and Torgrim Solstad, as well as to four anonymous reviewers, for valuable comments on earlier versions of this paper. I am also indebted to Annika Deichsel, Cornelia Ebert, Klaus von Heusinger, Jaklin Kornfilt, and Arndt Riester for helpful comments and discussions during the initial stages of this work. Research reported in this paper was funded by the SFB 732 at Stuttgart University as part of the project Discourse particles. Incremental interpretation in context.

\section{References}

Altmann, H. 1976. Die Gradpartikeln im Deutschen. Tübingen: Niemeyer.

Blakemore, D. 1989, Denial and contrast: A relevance theoretic analysis of but. Linguistics and Philosophy 12, 15-37.

Blakemore, D. 2002. Relevance and Linguistic Meaning: The Semantics and Pragmatics of Discourse Markers. Cambridge: Cambridge University Press.

Breindl, E. 2008. Die Brigitte nun kann den Hans nicht ausstehen. Gebundene Topiks im Deutschen. In: Breindl \& Thurmair (eds.). Erkenntnisse vom Rande. Zur Interaktion von Prosodie, Informationsstruktur, Syntax und Bedeutung. (= Themenheft Deutsche Sprache 1/2008), 27-49.

Büring, D. 1997. The Meaning of Topic and Focus - The 59th Street Bridge Accent. London: Routledge.

Büring, D. 2003. On D-Trees, Beans, and B-Accents. Linguistics \& Philosophy 26(5), 511-545.

Büring, D. and K. Hartmann 2001. The syntax and semantics of focus-sensitive particles in German. Natural Language and Linguistic Theory 19, 229-281. 
Chafe, W. 1976. Givenness, contrastiveness, definiteness, subjects, topics and points of view. In: C. Li (ed.). Subject and Topic. New York: Academic Press, 27-55.

Daneš, F. 1974. Functional sentence perspective and the organization of the text. In F. Daneš (ed.), Papers on Functional Sentence Persepctive. Prague: Academia/The Hague: Mouton, 106-128.

Dascal, M. and Katriel, T. 1977. Between semantics and pragmatics: The two types of "but" Hebrew "aval" and "ela". Theoretical Linguistics 4, 143-172.

Deichsel, A. and E. Karagjosova 2011. On the distributional constraints and discourse function of German discourse particles in postinitial position. Paper presented at the conference Moskow Syntax and Semantics 2, April 22-24, Moskow.

Frey, W. 2004. A medial topic position for German. Linguistische Berichte 198, 153-190.

Götze et al 2007. Information structure. In: S. Dipper, M. Götze and S. Skopeteas (eds.), Interdisciplinary Studies on Information Structure 07, 147-187.

Jacobs, J. 1997. I-Topikalisierung. Linguistische Berichte 168, 91-133.

Jacobs, J. 2001. The dimensions of topic-comment. Linguistics 39, 641-681.

Kamp, H. 2004. Information structure in a dynamic theory of meaning. In Proceedings of the Linguistic Society of Korea.

Karagjosova, E. 2009. Towards a DRT-based account of adversative connectors. In Working papers of the SFB 732, University of Stuttgart.

Karagjosova, E. 2011. Nämlich: Towards a unified account. Oral presentation at the DGfS Conference, Göttingen.

Krifka, M. 1992. A compositional semantics for multiple focus constructions. In Informationsstruktur und Grammatik, Sonderheft der Linguistischen Berichte, ed. Joachim Jacobs.

Krifka, M. 1999. Additive particles under stress. In Proceedings of SALT 8. CLC publications, Cornell: 111-128.

Krifka, M. 2007. Basic notions of information structure. In C. Fery and M. Krifka (eds.), Interdisciplinary Studies of Information Structure 6, Potsdam.

Lagerwerf, L. 1998. Causal connectives have presuppositions. The Hague: Holland Academic Graphics.

Lakoff, R. 1971. Ifs, ands, and buts about conjunction. In C. Fillmore and D. Langendoen (eds.) Studies in Linguistic Semantics. New York: Holt, Reinhart and Winston, $115-150$.

Lang, E. 1984. The Semantics of Coordination. Amsterdam-Philadelphia: John Benjamins.

Lang, E. 2004. Schnittstellen bei der Konnektoren-Beschreibung. In H. Blühdorn, E. Breindl and U. H. Waßner (eds.). Brücken schlagen. Grundlagen der Konnektorensemantik. Berlin/New York: de Gruyter, 45-92.

Metrich, R. 2003. Gehören nach-erstgestellte Elemente zu den Fokuspartikeln? In D. Baudot and I. Behr (eds.). Funktion und Bedeutung. Modelle einer syntaktischen Semantik des Deutschen. Festschrift für Francois Schanen. Tübingen: Stauffenburg, 177-198. 
Metrich, R. and G. Courdier 1995. Die Zukunft des Menschen aber ist immer so lang wie seine Vergangenheit. In R. Metrich and M. Vuillaume (eds.). Rand und Band. Abgrenzung und Verknüpfung als Grundtendenzen des Deutschen. Festschrift für E. Faucher zum 60. Geburtstag. Tübingen: Narr, 275-297.

Müller, S. 2003. Mehrfache Vorfeldbesetzung. Deutsche Sprache 31(1), 29-62.

Müller, S. 2005a. Zur Analyse scheinbarer V3-Sätze. In F.-J. d'Avis (ed.). Deutsche Syntax: Empirie und Theorie. Symposium Göteborg 1315 Mai 2004, Göteborger Germanistische Forschungen, 173194.

Müller, S. 2005b. Zur Analyse der scheinbar mehrfachen Vorfeldbesetzung. Linguistische Berichte 203, 297-330.

Müller , G. and W. Sternefeld 1993. Improper movement and unambiguous binding. Linguistic Inquiry 24, 461-507.

Pasch, R. et al. 2003. Handbuch der deutschen Konnektoren. Berlin: de Gruyter.

Reinhart, T. 1981. Pragmatics and linguistics: An analysis of sentence topics. Philosophica 27: 53-94.

Reis, M. 2005. On the syntax of so-called focus particles in German a reply to Büring/Hartmann 2001. Natural Language and Linguistic Theory 23, 459-483.

Roberts, C. 1996. Information structure in discourse. Ohio State University Working Papers in Linguistics 49, 91-136.

Roberts, C. 2011. Topics. In: C. Maienborn, K. von Heusinger \& P. Portner (eds.). Semantics: An International Handbook of Natural Language Meaning. Vol. 3. Berlin: de Gruyter.

von Stechow, A. 1990. Focusing and backgrounding operators. In: Discourse Particles, Pragmatics and Beyond. Amsterdam: John Benjamins, 17-84.

Steube, A. 2000. Ein kognitionswissenschaftlich basiertes Modell für Informationsstrukturierung. In: Ch. Römer and J. Bayer (eds.). Von der Philologie zur Grammatiktheorie. P. Suchsland zum 65. Geburtstag. Tübingen: Niemeyer, 213-238.

Steube, A. and A. Späth 2002. Semantik, Informationsstruktur und grammatische Modularität. Linguistische Arbeitsberichte 79, 235-254.

Sæbø, K. J., 2003. Presupposition and contrast: German aber as a topic particle. In: Weisgerber (Hg.), Proceedings of Sinn und Bedeutung 7, 257-271.

URL http://folk.uio.no/kjelljs/Research.htm

Sæbø, K. J., 2004. Conversational contrast and conventional parallel: Topic implicatures and additive presuppositions. In Journal of Semantics 21, 199-217.

Umbach, C. 2005. Contrast and information structure: A focus-based analysis of but. Linguistics 43(1), 207-232.

Umbach, C. and M. Stede 1999. Kohärenzrelationen: Ein Vergleich von Kontrast und Konzession. KIT-Report 148, Technische Universität Berlin.

Winterstein, G. 2010. La dimension probabiliste des marqueurs de discours. Nouvelles perspectives sur l'argumentation dans la langue. Ph.D. dissertation, Université Paris Diderot-Paris 7.

Winterstein, G. and H. Zeevat this issue. Empirical constraints on accounts of too. 